\title{
LOS SISTEMAS DE REGADÍOS TRADICIONALES DEL RÍO ALGAR-GUADALEST (LA MARINA BAIXA, ALICANTE): PATRIMONIO CULTURAL HIDRÁULICO MEDITERRÁNEO
}

Jorge Hermosilla Pla

Estepa. Departament de Geografia, Universitat de València*

\section{RESUMEN}

Durante siglos se ha ido configurando un contrastado patrimonio relacionado con los diversos sistemas de regadíos distribuidos por el río Algar y su afluente el Guadalest. Como en otras cuencas hidrográficas mediterráneas de dimensiones ajustadas, el medio físico y el proceso histórico han condicionado las arquitecturas hidráulicas de los regadíos tradicionales, su naturaleza, composición y morfología, los elementos que los constituyen, así como las etapas de su construcción a lo largo de siglos. Un rasgo común de los sistemas de regadío de este territorio es su diversidad, desde los riegos fluviales a los procedentes de captaciones subterráneas. El análisis realizado mediante la consulta de la documentación disponible y una minuciosa labor de estudio ha sido la base del presente artículo.

Palabras clave: Regadíos históricos mediterráneos. Sistemas hidraúlicos. Paisajes del agua. Patrimonio cultural.

\footnotetext{
* Este artículo procede del proyecto de investigación financiado por la Dirección General de Patrimonio Cultural Valenciano, en el programa de estudio de los regadíos históricos valencianos (2010). Estepa. Estudios del Territorio, Paisaje y Patrimonio. Jorge Hermosilla Pla (director), Emilio Iranzo García, Miguel Ángel González Ferrairó, Juan Ortiz Gómez, José Vicente Aparicio Vayá, Miguel Antequera Fernández, Roberto Escrivá Almiñana, Sandra Mayordomo Maya, Laura Serrano Victoria, Ghaleb Fansa, Mónica Fernández y Joaquín Panella Piera.
} 


\section{SUMMARY}

Traditional irrigation systems of the river Algar-Guadalest (La Marina Baixa, Alicante): Mediterranean hydraulic cultural heritage

For centuries a proven heritage has been configured related to the various systems of irrigation distributed by the Algar River and its tributary the Guadalest. As in other Mediterranean basins of fitting dimensions, the physical environment and the historical process have conditioned the hydraulic architecture of the traditional irrigation systems, its nature, composition and morphology, the elements that constitute them, as well as the stages of its construction over centuries. A feature common in irrigation systems of this territory is their diversity, from the river irrigation to groundwater catchments. The analysis carried out by the consultation of the documentation and a thorough work of study have been the basis of this article.

Keywords: Mediterranean Historical Irrigations. Hydraulic systems. Water landscapes. Cultural heritage.

UNAS CONDICIONES MEDITERRÁNEAS PARA UNOS REGADÍOS TRADICIONALES EN LA CUENCA DEL RÍO AlgAR-GUADALEST

Durante los últimos 15 años, de forma ininterrumpida, la unidad de investigación ESTEPA de la Universitat de València venimos abordando el análisis de los regadíos tradicionales de la cuenca mediterránea, en particular del sector oriental de la península Ibérica. Los diferentes estudios que hemos abordado nos ha permitido identificar unos rasgos comunes que facilitan la definición de los regadíos históricos mediterráneos; rasgos que fueron destacados en el Boletín de la AGE, en el número 64 (Hermosilla e Iranzo, 2014). Son paisajes culturales mediterráneos, coherentes con el medio físico; responden a unas condiciones espaciales particulares, basadas en la universalidad, la invisibilidad, la versatilidad y la complejidad del uso del agua; se basan en diversas arquitecturas asentadas en redes de acequias, que constituyen el armazón de unos paisajes singulares, que adquieren configuraciones espaciales diferentes; atesoran una incuestionable riqueza patrimonial, tanto material como inmaterial, en donde la historia constituye un factor capital.

Sin embargo los territorios preservan unas propiedades singulares cuando se analizan con el detalle y el rigor que precisan los trabajos del regadío tradicional, de manera que para cada cuenca hidrográfica, la unidad de trabajo habitual, cabe reseñar especificidades que han sido generadas por el medio físico y por el proceso histórico. Es el caso de la cuenca del río Algar y su afluente el Guadalest, que como acontece en otras cuencas similares (Gorgos, Girona, Amadorio...), sus regadíos siguen las pautas comunes de los espacios irrigados mediterráneos y del mismo modo se caracterizan por unos rasgos particulares, que le otorgan un valor patrimonial adicional. 
El área de estudio se localiza en el sector septentrional de la comarca de la Marina Baixa, ocupa más de 200 kilómetros cuadrados, un tercio de la comarca. El relieve presenta una configuración muy accidentada; sirva de testimonio que tres de los cuatros picos de mayor altitud de la provincia se localizan en la zona de estudio: la sierra de Aitana (1.558 m), el Puig Campana (1.408 m) y la Serrella $(1.379 \mathrm{~m})$.

La cuenca del Algar-Guadalest se subdivide en tres sectores: el primero, el más septentrional, abarca desde el nacimiento del Algar hasta la confluencia con el Guadalest; el segundo, en el suroeste, queda articulado en torno al Guadalest; por último, el sector oriental, una vez confluyen los dos ríos, en el término municipal de Altea, hasta su desembocadura. El sistema Algar-Guadalest recibe las escorrentías de doce de los dieciocho términos municipales que conforman la Marina Baixa (Altea, Beniardà, Benifato, Benimantell, Bolulla, Callosa d'en Sarrià, Castell de Guadalest, Confrides, La Nucia, Polop de la Marina y Tàrbena), mientras que los seis restantes forman parte de la cuenca Sella-Amadorio (Sella, Finestrat, Benidorm, Relleu, Orxeta y la Vila Joiosa).

La subcuenca del riu Algar tiene una superficie de $72,8 \mathrm{~km}^{2}$ y una longitud de recorrido cercana a los $15 \mathrm{~km}$. El riu Algar nace en la serra del Ferrer (Tàrbena-Callosa), y recorre la comarca en sentido norte-sur, recogen las escorrentías de las laderas occidentales de la serra de Bèrnia. Es precisamente en las faldas de Bèrnia donde se encuentra el conjunto de surgencias formadas por les Fonts de l'Algar, en el término de Callosa d'en Sarrià. En este mismo punto, y por la margen derecha, el ríu Algar recibe al barranc de Bolulla, de escaso caudal, que recoge las aguas del valle del mismo nombre. Aguas abajo, se encuentra el Canal Bajo del Algar, que tiene su toma en la presa del Paredó, donde existe la estación de bombeo de agua al embalse de Guadalest para el abastecimiento gestionado por el Consorcio de la Marina Baja.

El afluente más importante del Algar es el ríu Guadalest cuya confluencia se produce a la altura de El Gepsar (Altea), donde se localiza la presa de Mandem que deriva sus aguas para riego. La subcuenca del riu Guadalest tiene una superficie de 122,5 $\mathrm{km}^{2}$. El Guadalest nace de la confluencia de los barrancos de Favara y Beniardà, al pie de la sierra de Serrella, en el término municipal de Confrides, y circula aproximadamente paralelo a la serra de Aixortà. En la parte alta del río se emplaza uno de los dos embalses principales del sistema de explotación, el embalse de Guadalest, con una capacidad de $13 \mathrm{hm}^{3}$ y una lámina de agua de 86 hectáreas.

El barranc de Favara es el principal receptor de las aportaciones superficiales y subterráneas de gran parte de la vertiente norte de la serra d'Aitana, así como de los excedentes del aprovechamiento urbano y agrícola que se realiza de las principales surgencias o manantiales (Partagat, Xorrets, Benialet, etc). Por otro lado, el barranc de Beniardà o barranc de Mela recoge las aportaciones 


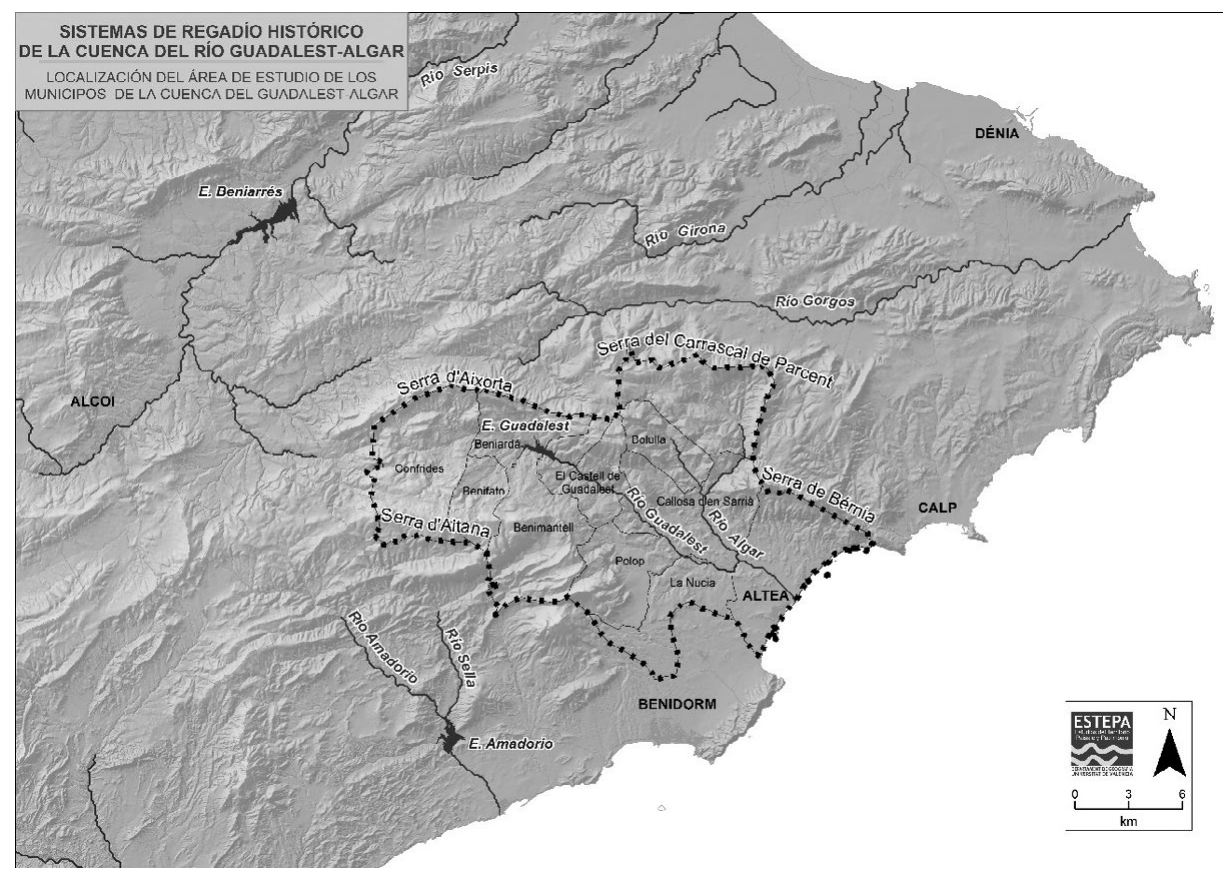

Figura 1. Localización del sistema Algar-Guadalest, Marina Baixa.

subterráneas del acuífero de Mela y es el principal eje de drenaje de la escorrentía superficial que se genera en el sector suroeste de la serra de Serrella.

El embalse de Guadalest recibe estas aportaciones superficiales, así como las aguas bombeadas desde la estación del Algar. Aguas abajo del embalse, la circulación de agua se limita al caudal ecológico y la escorrentía que se genera a partir de las escasas precipitaciones en la cuenca no regulada. En las cercanías de Polop se incorporan aguas procedentes del barranc de Xirles, cuando las intensas precipitaciones producen la descarga en las surgencias existentes cerca del río.

Por último, el tercer subsector se localiza en el curso bajo del río, ya próximo a su desembocadura en el Mediterráneo y tras haberse producido la confluencia entre ambos cursos. Desde ahí hasta la desembocadura en la bahía de Altea, el cauce posee una longitud inferior a $5 \mathrm{~km}$ y un área de drenaje de algo más de $20 \mathrm{~km}^{2}$.

\section{Un relieve dominado por su carácter accidentado}

Enmarcada en el conjunto del Sistema Bético, la zona de estudio es una sucesión de anticlinales y sinclinales, y algunos cabalgamientos con una dirección principal N60-70E, conocida como dirección bética. Este relieve estructural está 
modelado por fallas normales y de salto en dirección con orientaciones variadas en torno a NO-SE, que retocan las cuencas intramontanas, hasta el punto de condicionar su morfología definitiva. Nos referimos a ejemplos como la falla de Guadalest-Bèrnia, que limita el afloramiento triásico de Altea y constituye el escarpe del Morro del Toix, o las fallas de Punta Bombarda y Les Caletes en Serra Gelada.

Desde el punto de vista geológico se aprecia un manifiesto contraste entre los macizos calcáreos, aislados por la erosión, y las depresiones margosas suavemente onduladas. El espacio geográfico en el cual localizamos la cuenca del Algar-Guadalest se caracteriza por un gran dominio diapírico en el cual se aprecian tres sectores: los bordes estrictos del diapiro, el área central o sinclinal de la Marina y los relieves meridionales.

a. Los bordes del diapiro. Se halla la serra de Bèrnia que constituye un verdadero eje fisiográfico para la región, y divisoria entre las comarcas de la Marina Alta y la Marina Baixa. Con un longitud de unos $12 \mathrm{~km}$ y una altura máxima de 1.128 m.s.n.m., forma un compacto promontorio macizo, cortado verticalmente sobre el mar. El eje septentrional de Serrella-Aixortà-Almedia y Bèrnia-Toix, tiene su réplica sur en el eje fisiográfico que forma el macizo de Confrides, la serra d'Aitana y el Tossal d'Orduña. Además, la serra d'Aitana representa la culminación orográfica de la provincia de Alicante con 1.558 m.s.n.m. En Aitana se inicia el formidable eje cretácico que, continuado en Bèrnia, constituye la dorsal de la estructura geológica de La Marina. Hacia el este, el Cretácico y el Triásico están cubiertos por conos de derrubios cuaternarios.

b. El sinclinal de La Marina. Esta amplia estructura sinclinal abarca una extensión aproximada de $150 \mathrm{~km}^{2}$, se halla encerrada dentro de la isohipsa de los $400 \mathrm{~m}$. Se conforma según un eje de dirección SO-NE y está limitado al norte por Bèrnia, al oeste por la serra de Cortina, al este por la serra Gelada y al sur se abre directamente sobre el mar. Esta es la región conocida propiamente como La Marina y en su eje enlaza directamente Alfàs del Pí y Benidorm. Presenta un dominio litológico predominantemente Cuaternario descansado sobre un subyacente Cretácico. La orientación del pliegue sinclinal SO-NE es la típica del sureste español. El límite occidental de esta estructura sinclinal viene constituido por la serra de Cortina (522 m.n.n.m.), estribación meridional del Puig Campana y anticlinal de segundo orden que sigue un eje de dirección SO-NE, cerrando por el lado meridional el término de Finestrat. La estratigrafía predominante corresponde al Mioceno. Entre 
Altea y Benidorm, el sinclinal de La Marina tiene un cierre neto: la serra Gelada.

c. Relieves meridionales. En el límite occidental de la comarca se levanta el espectacular relieve del Puig Campana, a más de $1.400 \mathrm{~m}$ de altura. El borde septentrional de la estructura sinclinal de Amaniellos-Tapiada constituye la falda meridional del Puig. En conjunto, el anticlinal del Puig Campana se muestra como un cierre periclinal, con un eje que va en dirección este-oeste, con influencias NE-SO y pinzando rápidamente al NE. Desde el Puig Campana parten una serie de glacis divergentes que constituyen una orla o faja entre el Puig y el mar. Entre Altea y La Vila Joiosa, y a partir de los 20-30 m de altura, comienza a levantarse el plano o glacis que a unos 300 m.s.n.m. enlaza con la estructura pedestal del Puig Campana. Se trata de glacis áridos o de piedemonte, formado por procesos de acumulación e incluso, en ciertas partes, de inundación. El espacio ocupado se extiende unos $300 \mathrm{~m}$ y a continuación se desarrolla un plano en glacis que ya no se interrumpe hasta Altea. Este glacis de erosión, que a partir de La Nucia, se desarrolla en las margas triásicas hasta el mar, y provoca pendientes notables.

\section{Los rasgos climáticos y los regadíos}

El clima de la Marina Baixa comparte características mediterráneas comunes, como son los veranos secos y calurosos con una marcada sequía estival, inviernos suaves y una estación otoñal muy lluviosa. No obstante, las diferencias de altitud, orientación, cercanía al mar y relieve da un lugar a un mosaico de climas locales, con teselas muy reducidas en determinadas áreas, y que acaban por condicionar diferentes paisajes agrícolas. Diferencias que han podido evaluarse merced a los valores de las 10 estaciones pluviométricas y 7 termopluviométricas. Con todo, nos hallamos con los siguientes valores: una temperatura media anual de $15,7^{\circ} \mathrm{C}$ y unas precipitaciones próximas a los $600 \mathrm{~mm} /$ año como media para el conjunto de la cuenca del Algar-Guadalest.

- Las diferencias térmicas. El contraste climático entre la franja litoral y la zona montañosa es de naturaleza térmica, ya que el incremento altitudinal provoca temperaturas más frescas en verano y endurecimiento del invierno. De la misma manera se observa diferencias entre el litoral y el interior como efecto de la continentalidad. Los valores medios anuales oscilan desde los $12^{\circ} \mathrm{C}$ en las zonas montañosas del noroeste hasta los $18^{\circ} \mathrm{C}$ en la costa sureste.

- Las precipitaciones también muestran diferencias. El análisis de las precipitaciones de la comarca de la Marina Baixa queda caracterizado por la escasez de lluvias (máxime si se compara con la Marina Alta), la 
existencia de una fuerte sequía estival y la elevada irregularidad interanual, aspectos, todos ellos, determinantes en la distribución y extensión de los regadíos. Las escasas lluvias se producen esencialmente durante los equinocios, otoño y primavera, en forma de bruscos aguaceros, de corta duración, pero de elevada intensidad. Según la clasificación de Papadakis (1966), el clima comarcal responde al tipo mediterráneo semiárido, caracterizado por la existencia de inviernos relativamente suaves y una estación seca bien definida (junio, julio y agosto). La precipitación media anual varía más de un $40 \%$ de unos sectores a otros, condicionada, en particular, por la exposición a los flujos lluviosos. Así, los observatorios de Alcalalí, Alcoleja o Tàrbena, situados a barlovento y con vertientes elevadas expuestas a los vientos del primer y segundo cuadrante, proporcionan las mayores cantidades anuales a nivel regional (entre 700 y $800 \mathrm{~mm} / \mathrm{año}$ ); mientras que hacia SE los volúmenes descienden considerablemente en puntos como Altea o Callosa d'en Sarrià (entre 400 y $500 \mathrm{~mm} / \mathrm{año}$ ). La escasa pluviosidad del sector meridional se debe a su posición a sotavento con respecto al flujo zonal dominante. La evolución pluviométrica presenta dos facciones diferenciadas al igual que casi todas las características físicas de la misma; por un lado, se encuentran las cuencas de los ríos Guadalest y Algar, en donde la pluviometría es relativamente elevada aunque irregular, su valor medio anual se sitúa entorno a los 600 y $650 \mathrm{l} / \mathrm{m}^{2}$. Por otro lado, los valores en la cuenca del Amadorio, si bien son más regulares, son sensiblemente inferiores, en torno a los $300 \mathrm{l} / \mathrm{m}^{2}$.

\section{Una evapotranspiración estacional irregular}

El déficit hídrico calculado, según el método de Thornthwaite, alcanza valores superiores a los $500 \mathrm{~mm} / \mathrm{año}$; un déficit de humedad que correspone al periodo entre los meses de enero a octubre. La ETP anual es de $824 \mathrm{~mm}$, con notables diferencias dependiendo de la época del año: los valores medios de ETP están comprendidos entre $23 \mathrm{~mm}$ en el mes de enero y los $138 \mathrm{~mm}$ en los meses de julio. La evapotranspiración real (ETR) ofrece valores inferiores $(450-650 \mathrm{~mm} /$ año) y están condicionados por la influencia de factores de carácter local. En conjunto, en los observatorios analizados se detecta un superávit en el balance hídrico en la mayoría de los meses; únicamente acusa un déficit durante los meses de verano (junio, julio y agosto), consecuencia de las altas presiones en altitud e inversiones de subsidencia que detienen los ascensos durante el verano, con precipitaciones medias mensuales inferiores a los $30 \mathrm{~mm}$. 


\section{Hidrogeología, el origen de las aguas subterráneas}

La gran complejidad geológica de la región en la que se encuentra este sistema hace que, aún hoy en día, las incertidumbres sobre sus límites y relaciones hidráulicas con otras formaciones de acuíferos sean muy elevadas (Alfaro, 2004). A grandes rasgos, se puede establecer que los límites del acuífero están formados por las margas y margocalizas del Neocomiense y las arcillas y yesos triásicos del Keuper en el sector septentrional. Al noreste, el acuífero queda confinado por las margas terciarias de la depresión de Benissa, las cuales se ponen en contacto tectónico debido a una falla de gran salto, así como por las margas y margocalizas del Neocomiense de la serra de Ferrer. Por último, el sector meridional limita con los materiales del Keuper, los cuales afloran asociados a una falla radial del diapiro de Altea por la que discurre el riu Bolulla.

El nacimiento del Algar se produce tras la confluencia de varias surgencias situadas a los pies del macizo de la serra de Bèrnia, discurriendo sus aguas a través de angostos desfiladeros hasta salir al valle abierto, que se dirige en dirección suroeste, para incorporar a su cauce las aguas del riu Guadalest. Las características hidrogeológicas de les Fonts del Algar evidencian un funcionamiento típicamente cárstico, con caudales que oscilan entre 50 y 900 1/s, aunque se han llegado a alcanzar caudales puntas superiores a $1 \mathrm{~m}^{3} / \mathrm{s}$. Los menores caudales se alcanzan en la época estival, mientras que los máximos se producen tras los periodos lluviosos. Como consecuencia de esta irregularidad, se registra un desfase provocado por las elevadas demandas, que suelen ser mayores en la época estival cuando se requiere más agua para la agricultura y el turismo; esto impide poder cubrir la demanda hídrica con los aportes naturales. Una herramienta de gestión empleada en muchas surgencias cársticas para adecuar la demanda a los recursos hídricos existentes es la regulación de manantiales mediante la realización de una o varias captaciones en las inmediaciones del manantial con objeto de bombear agua durante la fase de agotamiento en que los caudales son insuficientes para cubrir las necesidades (época estival), y tomando el agua cuando el manantial aporta caudal suficiente de forma natural (época invernal). De esta forma se optimiza el aprovechamiento de los recursos con los mínimos costes. Esta estrategia de gestión ha sido la empleada en las Fonts de l'Algar mediante la realización de una batería de sondeos desde 1979 situados aguas arriba del Barranc de Sacos. No obstante, los intensos bombeos llevados a cabo en estos sondeos han alterado el régimen natural de descarga de los manantiales, hasta el punto de llegar a agotarlos durante la época estival y en periodos de sequía. Al igual que las surgencias, parte del agua bombeada se vierte al río, lo que permite el aprovechamiento turístico de este paraje.

La cuenca del Algar-Guadalest se corresponde a las siguientes Unidades Hidrogeológicas: 
- U.H.G. n. ${ }^{\circ} 45$ (Aitana): emplazado en el sector meridional de la cuenca del Guadalest, está conformada mayoritariamente por calizas del Eoceno. Como principales manantiales en la vertiente septentrional se puede destacar la Font del Partagat y la Font Vella.

- U.H.G. n. ${ }^{\circ} 46$ (Serrella-Aixortà-Algar): se localiza en el extremo septentrional de la cuenca y está constituido por calizas y dolomías Cenomaniense-Turoniense y cuya principal descarga se produce a través de la les Fonts de l'Algar y la Font Major de Callosa, y la Font de l'Assut de Bolulla.

- U.H.G. n. ${ }^{\circ} 47$ (Penyó-Montgó-Bèrnia): Esta formada por un conjunto de acuíferos con funcionamiento más o menos independiente entre sí. Sus límites hidrogeológicos vienen dados por la presencia de materiales impermeables del Trías Keuper o de accidentes tectónicos que impiden la continuidad de las formaciones acuíferas (IGME, 1986).

EL PROCESO HISTÓRICO DE CONFIGURACIÓN DE LOS REGADÍOS DE LAS VEGAS DEL GuAdalest-Algar

\section{Una historia de siglos, unos sistemas hidráulicos centenarios}

Los valles de los ríos Algar y Guadalest entraron de lleno en la historia del regadío durante la época musulmana, en concreto a partir del siglo XI, con la división del Califato de Córdoba en numerosas taifas. La taifa de Denia señoreó los valles interiores de la Marina a partir de 1010. Fue entonces cuando se inició un continuado crecimiento demográfico que sólo se vió alterado negativamente tras la expulsión de la población morisca de 1609. Los musulmanes estaban organizados en distritos castrales o aljamas, y éstos a su vez se dividían en alquerías. Tras la conquista del territorio por Jaime I durante la década de 1240 el territorio de la Marina permaneció mayoritariamente poblado por musulmanes bajo la tutela de señoríos feudales cristianos. Tras una primera época en el que la totalidad del territorio de estudio quedó bajo el dominio del caballero Bernat de Sarrià, a partir del siglo Xv se consolidaron los señoríos que habrán de llegar hasta el final del Antiguo Régimen: la Baronía de Confrides, La Baronía de Polop, El Marquesado de Guadalest, La Baronía de Callosa, la Baronía de Bolulla, la Baronía de Tàrbena y la Baronía de Altea fueron las unidades feudales en las que se dividió el territorio (Amillo, 2007).

Las Germanías afectaron gravemente a la población musulmana tras la represión sufrida por los agermanados en el contexto de una lucha antiseñorial en la que los musulmanes eran considerados aliados de los señores. La población mudéjar de Polop pereció asesinada por la mano de los agermanados capitaneados por Vicent Peris. La expulsión de los moriscos decretada en 1609 vació literalmente la comarca de la Marina, con lo que a partir del siglo XVII se inicia 
una segunda época. Una oleada de Cartas Puebla permitió la repoblación de la cuenca del Algar-Guadalest, si bien nunca se llegó a los niveles de población anteriores. La segunda mitad del siglo XVII, trajo consigo una época de notable crecimiento económico y poblacional que se tradujo en la construcción de nuevos molinos y sistemas de regadíos, como el Rec Nou de Altea o el Rec Major de l'Alfàs, a la par que se pusieron de nuevo en explotación los sistemas de regadío de corte musulmán en las montañas y en los valles fluviales. El paisaje de regadío y las infraestructuras de los tiempos actuales son herederos directos de aquella nueva sociedad que inició su andadura a partir de la repoblación de la segunda mitad del siglo XVII, pero en numerosas ocasiones con precedentes anteriores.

La abundancia de recursos hidrológicos circulantes y subterráneos en la cuenca hidrográfica del Algar-Guadalest contrasta con la mayor aridez de los valles contiguos. Ni el valle del riu Gorgos, al norte, ni el Amadorio, al sur, ni el Seta a occidente cuentan con una proporción de aguas en sus lechos ni semejante. Su profuso poblamiento musulmán, ininterrumpido al menos desde el siglo XI hasta el XVII, permitió la puesta en marcha de centenares de sistemas de irrigación a partir de manantiales, galerías horizontales, azudes y boqueras, que fueron heredados, mantenidos y extendidos por los cristianos, tras la conquista de Jaime I, en algunos lugares como Callosa d'en Sarrià, pero sobre todo, tras la expulsión de los moriscos a partir de 1609 y la consiguiente repoblación por parte de los cristianos de las explotaciones agrícolas abandonadas. Se ha analizado documentalmente los regadíos del Vall de Guadalest, de la Vall de Tàrbena, de la Font Major y de derivación fluvial en Callosa d'En Sarrià, de la Baronía de Polop, Rec Major de Polop, y en Altea, el Rec Major i de Baix, el Rec Nou o de Dalt, y Rec d'Altea la Vella.

\section{Regadios del Vall de Guadalest}

Vi la hermosa fuente de la Forata, que arroja un caño de agua como el brazo, y después las llamadas Vella y Partagát, todas preciosas por la pureza, frescura y calidad de sus aguas, que compiten con las de Mariola... «cada pueblo del valle tiene su fuente cristalina, y unidos los caudales de todas sirven para regar 300 jornales de huerta hermosa y fértil, donde se dan todas las producciones del reyno, exceptuando el arroz. Estas impresiones del erudito valenciano Cavanilles (1797), testimonian tanto la riqueza de las aguas como el secular aprovechamiento de los recursos hídricos del Vall de Guadalest para el regadío. En el Llibre del Repartiment de Jaume I se encuentra una donación de 0,5 hectáreas de huerta en Guadalest, (Ferrer Navarro, R, 1999), única donación expresa de terreno huertano de todos los pueblos de la Marina estudiados. Esta circunstancia pone de manifiesto la gran continuidad histórica de la huerta 
del valle de Guadalest. Mientras las grandes vegas de Altea y de Callosa d'en Sarriá tendrán un impulso cristiano, los regadíos de Guadalest son de marcado carácter islámico. Fracasada la repoblación cristiana del siglo XIII, los musulmanes seguirán cultivando sus tierras por espacio de cuatro siglos más, ya bajo dominio feudal cristiano.

Las características del regadío tradicional de la baronía de Confrides y del Marquesado de Guadalest son las propias de las de un valle musulmán dotado de numerosas fuentes y de un curso fluvial permanente. Cada alquería musulmana aprovechaba los recursos de la surgencia (fuente o galería drenante) que había motivado su existencia. A la par, las aguas circulantes por el riu Guadalest y por las barrancadas eran derivadas hacia los márgenes. Así, la Séquia del Rec del Molí a partir del barranc de Matxelis en Confrides, la foggara de Mela en l'Abdet, las fuentes del Pertegat y dels Xorrets en Benifato, la foggara de Benialet, en Beniardà, la font del Molí en Benimantell o la font d'Ondarella en Castell de Guadalest son un buen reflejo de los referidos añejos sistemas de regadío. Tras la expulsión de los moriscos en 1609 y el consecuente vacío del valle, los nuevos colonos cristianos de Confrides y del Vall de Guadalest recibieron un total de 1.338,2 hectáreas de huerta (Plá Alberola, P, 1983). Tras la reordenación del espacio, desaparecieron varias alquerías, que no se volvieron a poblar nunca, sin embargo la totalidad de fuentes y huertas continuaron siendo explotadas por los repobladores cristianos. Antiguos poblamientos del valle como Benisecli, Ondarella o Muxaraques persisten en el recuerdo gracias al mantenimiento y uso hasta la actualidad de las fuentes que fueron su razón de ser.

\section{Regadios de la Vall de Tàrbena}

El valle de Tàrbena estuvo poblado por musulmanes desde al menos el siglo XI hasta la expulsión decretada en 1609. Los regadíos montanos propios de los valles altos del interior valenciano tienen en el valle de Tàrbena uno de sus mejores exponentes. Cavanilles, en su paso por Tàrbena a finales del siglo XVIII estableció la siguiente descripción: Es muy quebrado aquel terreno, pero hay sitios pingües, y aguas para regar algunos campos... parece imposible sacar de alli tantos y tan preciosos frutos.... La descripción refiere un paisaje montañoso y mayoritariamente de secano, pero no exento de regadíos tradicionales aprovechados con dedicación y ahínco encomiables. El paisaje del regadío en el Valle de Tàrbena es el del aprovechamiento secular de manantiales, galerías y aguas circulantes por las numerosas barrancadas existentes. Pequeñas albercas almacenan los recursos hídricos extraídos del subsuelo para la gestión de los bancales anexos. Este uso multisecular de las aguas posee una matriz musulmana, microsistemas de regadío que adoptan los colonos cristianos a partir del siglo 
XVII. Tanto las infraestructuras como los usos del agua son de una tecnología desarrollada, que como sucede en todo el arco mediterráneo, los nuevos campesinos cristianos simplemente heredan, sin innovaciones dignas de mención y se convierten en continuadores de un paisaje fosilizado en las laderas de las montañas consistente en manantial, galería o toma de agua, alberca gestionadora del riego y terrazas abancaladas que son beneficiadas por el riego a partir de pequeñas acequias. En Tàrbena, las Fuentes del Mig, de Casinvanyes, de Benissalim, de Buixcarró, de la Murta, de L'Hort o de Baix son sólo una muestra de los incontables aprovechamientos hidráulicos existentes en el escarpado término municipal. Algunas de las fuentes abastecieron antiguas alquerías musulmanes que fueron abandonadas tras la expulsión de los moriscos y que nunca fueron repobladas por los colonos cristianos posteriores. Otro aprovechamiento notable del término municipal ha sido históricamente el uso de los recursos que desde la Font Grossa circulaban por el barranc de Binarreal.

\section{Regadio de la Font Major de Callosa d'en Sarrià}

Se trata del aprovechamiento hidráulico más antiguo de Callosa d'en Sarrià. Situada la población en torno al promontorio donde se ubicaba el castillo roquero, creció el caserío lejos de los cursos fluviales de los ríos Algar y Callosa. Tras la conquista de Jaime I, Callosa se convirtió en uno de los pocos lugares poblados con cristianos, a excepción de las pequeñas guarniciones de los castillos. Las heredades bonificadas por la Font Major, de posesión musulmana con anterioridad, fueron repartidas entre los colonos cristianos. No contamos con datos exactos sobre las parcelas directamente beneficiadas por la fuente, pero en el Llibre del Repartiment, está documentado el reparto de 720 hectáreas de Tierra Campa -la mayor donación de tierras de la comarca- (Ferrer Navarro, $\mathrm{R}, 1999)$. Frente a otros lugares del interior de la Marina, que persistieron tras la conquista cristiana habitados por musulmanes, Callosa consolidó un poblamiento cristiano duradero, y si bien existió morería en la villa, los musulmanes serían desplazados de las mejores parcelas beneficiadas por la Font Major y se concentraron progresivamente en las alquerías de Micleta y Algar. De este modo, ya en 1459, en tiempos del señor de Callosa, En Pere Bou consta que se distribuía por horas el uso del agua de la Font Major para riego y que se efectuaron obras de consolidación del cajero de la acequia (Salvà, A, 1936). El riego de la Font Major fue el más importante de Callosa d'en Sarrià durante siglos. Habrá que esperar hasta los siglos XVIII-XIX para que las nuevas acequias de derivación fluvial se consoliden en los lechos de los ríos Algar y Guadalest, con la siempre oposición de Altea, que pleiteó en varias ocasiones para que esos nuevos canales callosinos no se llevaran a cabo. El origen de Callosa, como el de otros municipios mediterráneos de interior está asociado a la existencia de 
un promontorio donde localizar una fortaleza defensiva y a la proximidad de una fuente de abastecimiento hídrico. La Font Major, por tanto, es el aprovechamiento hidráulico que ha permitido el desarrollo de la villa de Callosa d'en Sarrià, del mismo modo que las desaparecidas alquerías de Micleta y Algar, se desarrollaron anexas a una o varias surgencias. La fuente poseyó desde el principio la doble funcionalidad de abastecimiento y de regadío. La tradicional primacía del abastecimiento humano frente al regadío está bien documentada a partir del siglo XVIII, con la construcción del lavadero (el Poador) y la creación de la Séquia del Retorn. En 1783, el Consejo General de Propios y Arbitrios del Reino autorizó a la villa de Callosa, la construcción de un lavadero y un abrevadero sobre el lecho de la Séquia de la Font Major (Salvà, A. 1960). Este es el origen del actual Poador, con sus doce caños. La techumbre del monumento se construyó entre 1926 y 1930. En 1859, se construyó la Séquia del Retorn, canal que desde el Poador retrocede hasta la Font Major. Se trató de una ingeniosa obra que pone de manifiesto la prioridad de los usos urbanos frente a la irrigación. Las aguas circulan hasta los caños del lavadero y sólo tras abastecer las necesidades vecinales, los caudales siguen su trayecto hasta la parte oriental del municipio o regresan hacia la Font Major para proceder a regar los campos situados aguas arriba del Poador. Los bancales, plantados en la actualidad de frutales y cítricos, ubicados en los márgenes meridionales y orientales del caserío representan los regadíos más antiguos de Callosa d'en Sarrià. Las modernas ordenanzas del Rec Major fueron aprobadas en 1881.

\section{Regadios de derivación fluvial en Callosa d'En Sarrià}

El término municipal de Callosa está bañado por los ríos Guadalest, Algar y Bolulla. En la actualidad, la Comunidad General de Regantes de Callosa d'en Sarrià gestiona un total de 26 sistemas de regadío derivados de los cauces fluviales citados. Si bien resulta lógico deducir un remoto uso de las aguas de los ríos aludidos para la irrigación, al menos desde tiempos musulmanes, los sistemas de regadío tradicional callosinos asociados a los cauces no alcanzaron su desarrollo hasta el siglo XIX. Son varios los motivos por los cuales no se desarrollaron los regadíos en torno a unos lechos fluviales poseedores de notable caudal: en primer lugar, los condicionamientos políticos (aguadas de las armadas reales en la costa de la Marina), en segundo lugar, el emplazamiento de los lugares habitados y finalmente, la oposición protagonizada por la villa de Altea a la instauración de regadíos en el tramo alto del riu Algar y en el lecho fluvial del riu Guadalest aguas abajo del barranc de Xirles. La descripción que el botánico Cavanilles realizó de las huertas de Callosa a finales del siglo XVIII son reveladoras de estas circunstancias: "La huerta de Callosa pasa de 500 jornales, y la porción principal de ella se halla entre los ríos Algár y Guadalést. Mayor 
sería si los vecinos pudieran aprovechar como ántes las aguas de Algár, cuyo nacimiento está 20 varas mas alto que los campos, y los industriosos labradores las dirigian por canales para fertilizar tierras que hoy carecen de riego, el qual se les prohibió á título de que alteraba la pureza y bondad de las aguas, tan necesarias en aquella costa para hacer aguada los buque. Sin embargo, el erudito valenciano ya planteaba que la excusa de la aguada era en gran parte falsa, porque había visto como las aguas llegaban con inmundicias al mar, lo que implicaba el uso de las aguas para regadío en el tramo inferior del riu Algar. Cavanilles estaba poniendo en evidencia una circunstancia que se repetirá de forma continuada a partir del siglo XVII: la primacía absoluta de Altea hacia las aguas circulantes por los ríos Algar y Guadalest, procedentes respectivamente de las fuentes del Algar y del barranc de Xirles (Fuentes de Bunea, Montroi y Xirles). Cuando los habitantes de Callosa al calor de la expansión demográfica del siglo XVIII reinician las iniciativas para crear nuevos regadíos en torno a los cursos fluviales se encontraron con la oposición de los regantes de Altea, que vencieron en todos los pleitos, como se verá más adelante. Todo intento de construcción de un canal de riego en los cauces fluviales por parte de los callosinos era mandado inmediatamente terraplenar a instancias de la Audiencia: Se imponen penas a los vecinos de Callosa de En Sarriá y que terraplenen la acequia que habian echo... Todavía en 1850 es posible encontrar una demanda de la Junta del Rec Nou d'Altea impuesta sobre los regantes de Callosa, en la que los alteanos pretendían recobrar el quieto y pacífico uso de las aguas de Montroi, Xirles y Bonea, excluyendo de su uso a los vecinos de Callosa (Pastor Fluixà, J, 2005). Los 26 sistemas de regadío de derivación fluvial localizados en el término municipal de Callosa d'en Sarrià y que cubren 60 kilómetros de acequias entre campos de cítricos y nísperos se consolidaron a partir de la segunda mitad del siglo XIX a consecuencia de las dificultades legales sostenidas por las autoridades alteanas. Las acequias de Algar-Raboset-Parats y Marxerquivir, puesta en funcionamiento en 1802, de Marxerquivir Nou, regulado en 1857, la del Pinar, que toma sus aguas desde el estrecho del riu Bolulla, y la Séquia de Ronda, que culminaba en el molino harinero homónimo son los sistemas de regadío callosinos más notables derivados desde el riu Algar. En el tramo del riu Guadalest, las acequias de la Algoleja, de Rutxei y la del Piquero representan los sistemas de regadío más importantes al servicio de los regantes de Callosa d'an Sarrià. Las acequias aludidas verán su consolidación definitiva a partir de la segunda mitad del siglo xIX y la Ley de aguas de 1866, es decir, que no funcionaron en alguno de sus tramos con anterioridad, como revela la demanda que el procurador de Altea interpone contra Vicent Ronda en 1777 por distraer aguas del Algar hacia su molino aludido (Séquia de Ronda actual) o la denuncia interpuesta contra los terratenientes de Algar, Raboset y Margerquivir en 1815 por estar obrando alcavones y acequias para hacer llegar el agua del riu Algar a sus campos. A partir de 
1850, legalizados y regulados los sistemas de riego, comienzan a ampliarse por las vegas de los cauces. Ya en el siglo xx, al compás del auge de los frutales, las acequias históricas se alargarán notablemente para poner en regadío bancales de secano situados en los extremos del término municipal.

\section{Regadios de la Baronía de Polop}

La Baronía de Polop estaba integrada por la villa de Polop, las morerías de Xirles y La Nucia y los lugares de Alfaz y Benidorm. Esta última localidad, adquirió trascendencia histórica a partir de la Carta Puebla de 1666, desligándose con el tiempo de la Rectoría de Polop. La historia de sus regadíos se puede sintetizar en tres hitos fundamentales: el aprovechamiento secular de los manantiales situados en los barrancos del Gulapdar y la Canal, en Polop; los pleitos por los recursos de las Fuentes de la Mata y el Tosalet, en el regadío de La Nucia; y finalmente, la creación del Rec Major d'Alfàs, que permitió el apogeo de Benidorm (Amillo, 2010).

a/ El Rec Major de Polop. Poseen un término con mucha extensión con abundantes aguas para el riego; y como la aplicación de los naturales compite con la fertilidad del suelo, sacan precios frutos... Cavanilles describe las excepcionales características naturales del paisaje de regadío de la baronía de Polop. Les Fonts del Braçalet o de la Salut, la Font del Terrer y la Font del Garrofer o Sirer son las surgencias que han posibilitado desde tiempos musulmanes la puesta en regadío de las heredades situadas en torno a la villa. De tiempo inmemorial, quizá de tiempos romanos, existe un paretó o gran azud, en la parte alta del barranco, que derivaba los recursos de las surgencias nacidas sobre el lecho fluvial, lo que demuestra el multisecular uso de las aguas de los barrancos de Polop para el regadío. Los aprovechamientos derivan desde los barrancos de Gulapdar y la Canal y corresponden a galerías drenantes y surgencias naturales puestas en explotación continuado al menos desde el siglo XI y heredadas por los nuevos colonos cristianos, a partir del siglo XIII, y de forma definitiva tras la expulsión morisca de 1609. Como en tantos otros lugares del Mediterráneo, los cristianos encontraron tan perfecta el modelo organizativo de los regadíos musulmanes que se limitaron a heredar sus usos. Existe un elemento histórico de gestión de aguas asociado a este riego: el partidor de la Séquia Major de Polop, que desde 1911, divide los caudales de las fuentes de Polop entre la Séquia del Rec Major de Polop, que goza de prioridad, y la Séquia del Rec Major de l'Alfàs, que recibe todos los caudales circulantes que superen los 86 litros por segundo.

b/ Les Fonts de la Mata y el Tosalet. Estas surgencias localizadas históricamente en término municipal de Polop, fueron explotadas durante siglos por los musulmanes de la baronía para el avenado de las parcelas de huerta y para el 
abastecimiento doméstico, como tantas otras surgencias situadas en los valles de la Marina. Será a raíz de la independencia jurisdiccional de la población de La Nucia, respecto a Polop, en 1705, cuando estas fuentes sean el motivo de una enemistad secular entre los habitantes de las dos poblaciones, resuelta felizmente durante el último siglo. En 1734, en la Concordia entre La Nucia y Polop, el término municipal otorgado a la primera población, resulta extraordinariamente vasto, e incluye en su dominio, las fuentes del contencioso (San José, F, 2010). Del mismo modo, en 1836, al producirse el amojonamiento entre los términos de Polop, La Nucia y el recién independizado Alfàs, el promontorio de Torrent, quedaba para La Nucia, por lo que las fuentes de La Mata y el Tosalet se incorporaban de manera definitiva con los manantiales. La ruptura intencionada de las acequias o la provisión de suciedad sobre las aguas de las que se beneficiaba La Nucia, resultaron hechos corrientes que distanciaron durante varios decenios las relaciones entre las dos poblaciones.

La partida de Sentinilla, situada en el término municipal de La Nucia se beneficia desde el siglo XIX de parte de los recursos de la Font del Gall, destinados en principio para el Rec Major de l'Alfàs. Una ruptura de la presa de este último riego a principios dfel siglo XIX, produjo la pérdida de caudales hacia la parte baja del barranco. Los agricultores de la partida de la Sentinilla aprovecharon estas aguas durante más de 20 años, por lo que adquirieron derechos de uso. Cuando los regantes de la Séquia Major de l'Alfàs quisieron recuperar esos caudales, se vieron con los pleitos que los regantes de La Nucia hicieron ante la Audiencia. De este litigio surgió uno de los elementos históricos de la comarca: El partidor de la Font del Gall, construido en 1907, divide los caudales en partes iguales entre los regantes respectivos del Rec Major de l'Alfàs y los de la partida de Sentinilla.

c/ El Rec Major de L'Alfàs. Junto con el Rec Nou de Altea, se trata del segundo de los dos grandes riegos, junto al Rec Nou de Altea, que se pusieron en marcha a partir de la segunda mitad del siglo XVII en la comarca, dentro del contexto de atracción de nuevos pobladores tras la expulsión de los moriscos. La acequia fue creada a instancias de Beatriz Fajardo de Mendoza, baronesa de Polop en 1666. El objetivo de la obra radicaba en el aprovechamiento de los caudales que discurrían por el barranc de Polop y que no eran aprovechadas por el Riego Mayor de esta localidad. Estos recursos hídricos se derivaron a partir de una acequia de nueva factura que permitió transformar en regadío 1.200 hectáreas de tierras de secano en los términos actuales de Polop, La Nucia, Alfàs del Pi y Benidorm. La Carta Puebla de Benidorm (1666), lugar a la sazón incluido en la baronía de Polop, posibilitó la repoblación de las tierras beneficiadas por los nuevos regadíos. La ciudad de Benidorm actual es heredera directa del nuevo poblamiento del siglo XVII, íntimamente ligado al suministro de agua del Riego Mayor del Alfaz. Doña Beatriz utilizó las infraestructuras existentes del molino 
harinero de Rovira, en la margen derecha del barranc de Polop, concediéndole derecho preferencial de agua. Las aguas sobrantes del barranc de Polop fueron concedidas al Rec Nou. La baronesa pretendió incorporar también los recursos de las fuentes que nacían en el barranc de Xirles, pero la oposición del Marqués de Aitona, señor de Callosa frustró este intento, al ser utilizados estos caudales para el movimiento del molino señorial de Callosa d'en Sarrià. El Rec Major de L'Alfàs fue uno de los pocos de la comarca que mantuvo siempre separada la propiedad del agua sobre la tierra. La propiedad del agua fue una de las regalías que los señores feudales de la baronía de Polop se reservaron siempre. En la tardía fecha de 1847, una Real Orden aún reglamentaba y establecía la división del riego entre «dominio útil» $\mathrm{y}$ «dominio directo». El señor es el dueño del agua y las infraestructuras y los campesinos son únicamente los usufructuarios. Habrá que esperar hasta 1912, cuando el Sindicato de Riegos de Alfaz negocie con los herederos de Bernabé Morcillo de la Cuesta, heredero del dominio directo sobre este riego, la venta de todos sus derechos y bienes relacionados con este sistema de regadío.

\section{Regadios de Altea}

En el estudio de los regadíos del actual término municipal de Altea es necesario afrontar de forma separada los regadíos asociados al casco urbano de Altea y los asociados a la pedanía de Altea la Vella. Este último núcleo, situado en las faldas meridionales de Bèrnia corresponde a la alquería y castro de Altea que Jaume I donó en 1262 a Albert de Mediona. En 1280, Pere el Gran otorgaba a unos ciudadanos de Lleida una carta puebla al lugar de Altea (Altea la Vella). Por otro lado, el señor de Polop, Bernat d'En Sarrià fundaba a comienzos del siglo XIV en la desembocadura derecha del riu Algar la población cristiana de Bellaguarda, dentro del contexto de fundaciones de plazas fuertes cristianas en la costa para vigilar la numerosa población musulmana del interior (Fundación de la Vila Joiosa y de Benidorm por parte del mismo Bernat d'En Sarrià). No obstante, la repoblación de estos dos emplazamientos fracasó hasta los siglos modernos (s.XVII-XVIII) a consecuencia de los constantes ataques de piratas berberiscos y corsarios y de la expulsión de los moriscos (1609). Cavanilles en su paso por la Marina Baixa a finales del siglo XVIII, encontró despoblado y derruido el lugar de Altea la Vella: «Estuvo esta (Altea la Vella) y aun quedan vestigios en la falda meridional del Bèrnia...». En otro orden, la Bellaguarda medieval, despoblada a lo largo del siglo Xv, comenzará su nueva andadura histórica a partir de la Carta Puebla otorgada por el marqués de Ariza en 1617. La construcción y desarrollo de las importantes infraestructuras de riego del término municipal de Altea comienzan en este punto, si bien pueden rastrearse canales de riego con anterioridad. La inexistencia de poblamiento musulmán previo impide, como en 
tantos otros lugares de La Marina y del Reino de Valencia otorgar el origen y desarrollo de los riegos a los musulmanes. Estamos, por tanto, ante infraestructuras hidráulicas de impulso exclusivamente cristiano.

\section{El Rec Major i de Baix}

Se trata del riego más antiguo de la villa de Altea, destinado a las parcelas más próximas al casco urbano. Es posible encontrar antecedentes de este riego durante la Baja Edad Media, si bien su desarrollo actual lo adoptará tras la exitosa repoblación del siglo XVII. Así, existen noticias de la existencia del Molí de Benimussa y su acequia desde los tiempos medievales (Pastor Fluixà, J, 2005). Poseemos del mismo modo, noticias sobre obras de acequias en el término de Altea en 1410: obres de la céquia que parteix de Balançat e va ves Benidorm. Es revelador el hecho de que la Carta Puebla de 1617 establece para cada colono cuatro jornales de huerta, que corresponden a terrenos beneficiados por el Rec Major (Pastor Fluixà, J, 2005). Podemos concluir, por lo tanto, con la certidumbre de que los pobladores de la antigua Bellaguarda habían puesto en funcionamiento el grueso de las obras del Rec Major. Abandonadas y olvidadas éstas durante dos siglos, se procede a reactivar este riego tras la repoblación iniciada en 1617. Este sistema de regadío persiste funcional en la actualidad y sus beneficiarios no necesitaron históricamente esperar tanda ni turno alguno para regar, a diferencia del otro gran sistema de regadío del municipio, el Rec Nou.

\section{El Rec Nou o de Dalt}

En el capítulo XIV de la Carta Puebla se establece una diferenciación entre los censos a pagar en caso de que las nuevas acequias sean construidas por el señor o lo sean por los vasallos. Este hecho demuestra el impulso que se pretendía dar a la construcción de nuevos regadíos en el término de Altea (Pastor Fluixà, J, 2005). Efectivamente, en 1652 se prolonga la Séquia del Rec Major y se inician las obras del Rec Nou, que no concluirán hasta después de la Guerra de Sucesión, en la primera década del siglo XVIII. La infraestructura del Rec Nou, una de las mayores de la comarca, transformará en regadío más de 300 hectáreas de secano a regadío. La obra beneficiaba del mismo modo al señor, que veía acrecentadas las rentas a recibir, como a los enfiteutas, que obtenían mayor productividad de los cultivos sometidos a riego. La Concordia de 1652 contemplaba que el señor costeaba la obra y los colonos prestarían la mano de obra. Las características más sobresalientes del Rec Nou se resumen en los siguientes epígrafes:

a. Reafirmación de las características feudales. El señor se reserva el agua para el molino señorial, con prioridad sobre el riego. Esta característica es prototípica del feudalismo frente al sistema musulmán, en el que los 
molinos se sitúaban al final del sistema de riego, utilizando únicamente sobrantes. Así, en la Concordia de 1652 entre el marqués y los enfiteutas queda claro que: en los años de esterilidad de agua, haya de ser preferido el molino al riego...

b. El señor territorial es el propietario de las aguas y de las acequias. Los campesinos sólo cuentan con el usufructo. Con el tiempo, el secular gobierno del riego por parte de labradores y propietarios hará que los derechos de propiedad del señor queden en el olvido. Derechos de propiedad que reverdecerán en las postrimerías del Antiguo Régimen. Por otro lado, las aguas del Rec Nou serán repartidas por tandas siguiendo un turno riguroso. Se diferencia claramente este régimen con el del Rec Major, que carecía de tanda.

c. La infraestructura del Rec Nou construida a partir de la segunda mitad del siglo XVII, coincide fielmente con el sistema de acequias y particiones existente en la actualidad. Desde el extremo del açut asta la Peña Negra: un ramal de cal y canto por ser falso el terreno. Y desde la Peña Negra, asta concluir la açequia en el Llano del Castillo [...] se a de proseguir para el término que llaman de los Arcos... En la actualidad, un partidor sigue dividiendo los caudales del Rec Nou entre el Braçal del Pla de Castell y el Braçal dels Arcs o Séquia Mare. También, cuando se hace mención a la tarea de los acequieros en las ordenanzas se pueden distinguir los tres grandes tramos de la acequia actual: obligados los anunciados cequieros a poner tres cabos de agua, a saber, uno en el Llano del Castillo (braçal del Pla del Castell), otro en los Arcos (braçal dels Arcs) y otro en las Quintanes (tramo de la Séquia del Rec Nou desde el azud hasta el partidor del Pla del Castell).

\section{El Rec d'Altea la Vella}

Esta pedanía, primigenio poblamiento en la costa de Altea, se asienta en las faldas meridionales de la Serra de Bèrnia. Junto a una barrancada que recoge los aportes de numerosos manantiales que nacen en un espacio de pocos metros (Font Gran, del Garroferet, de L'Ama). En origen fue una alquería musulmana y las primeras canalizaciones de transporte de aguas de los referidos manantiales para regar las parcelas anexas al poblado sería obra de los musulmanes. Tras la conquista del territorio por Jaime I y las revueltas mudéjares de Alazraq, Pedro el Grande otorgó una carta puebla al lugar de Altea el 22 de Abril de 1280, correspondiente a la actual ubicación de Altea la Vella. La repoblación fracasó y el núcleo alteano estuvo habitado durante periodos alternos por población mudéjar, si bien la cercanía al mar, produjo el abandono definitivo del enclave hasta el siglo XVII a causa de las incursiones corsarias y de piratería. La 
definitiva puesta en marcha de los regadíos de Altea la Vella serán obra cristiana a partir de la repoblación del siglo XVII. A partir de les Fonts del Garroferer, Major, de l'Ama y otras surgencias menores fue diseñado un complejo sistemas de acequias encargadas de irrigar las faldas meridionales de la serra de Bèrnia y la margen izquierda de la desembocadura del riu Algar. La particularidad de los regadíos de Altea la Vella es el hecho de su adscripción al modelo yemení, esto es, la separación total de la propiedad del agua sobre la de la tierra. Ambas propiedades se pueden vender por separado.

IDENTIFICACIÓN Y DIMENSIÓN DE LOS REGADÍOS HISTÓRICOS DE LA CUENCA DEL Algar-Guadalest

Análisis de los sistemas de regadío en la cuenca del Algar-Guadalest

La fotografía aérea de 1956 desvela que se regaban en la cuenca del GuadalestAlgar 1.505 hectáreas, cuando en el 2008 algo más de 3.380 hectáreas. La misma fuente documental nos revela las manifiestas diferencias entre los sistemas de irrigación de las cuencas alta y baja. En el sector más elevado hallamos riegos poco extensos, con sistemas que no alcanzan el kilómetro de longitud y escasas hectáreas de riego, salvo excepciones como la Font del Molí de Benimantell, o el sistema originado en la Font de Benialet entre Benifato y Beniardà. Aguas abajo, sin embargo, se encuentran los riegos de Altea, Callosa d'en Sarrià, La Nucia y Polop de la Marina, cuyos sistemas se prolongan en kilómetros y alumbran más de un centenar de hectáreas.

El trabajo de campo nos ha permitido identificar tres tipologías de sistemas de riego en función del origen de los recursos hídricos: los riegos fluviales, tanto de ríos como de barrancos; las tierras bonificadas por medio de manantiales, fuentes, galerías drenantes o nacimientos; y los riegos mixtos, aquellos que combinan diversos tipos de captaciones, superficiales y subterráneas. Los riegos fluviales son sistemas por lo general de mayor longitud y abarcan una superficie que suele superar las 15 hectáreas, salvo en las cabeceras de los cursos, que son más reducidas. Cuentan con elementos patrimoniales adscritos a ellos de una relativa sencillez, aunque este hecho no les resta valor y calidad técnica. Los elementos más frecuentes que se encuentran en las acequias que emanan de los ríos son: azudes (captación), minados de transporte y acueductos (salvan dificultades orográficas), lavaderos, partidores o derramadores. Los riegos de fuentes, galerías drenantes o nacimientos presentan, por regla general, diferencias notables en cuanto a longitud y superficie de los sistemas, y a los conjuntos patrimoniales asociados a ellos. El recorrido de este tipo de acequias es con frecuencia de menor longitud y superficie, aunque existen excepciones como la Font Major de Callosa d'en Sarrià, la Font del Molí de Benimantell, la Font de Benialet en Benimantell o la Font de la Favara en La Nucia. Los elementos 
patrimoniales ligados a estos sistemas requieren mayor complejidad, se presentan en distintas agrupaciones, y es menos frecuente elementos patrimoniales aislados. Hay algunos factores singulares relacionados con el menor caudal disponible, como son las numerosas albercas; con la red de caminos ganaderos (veredas, cordeles...), por lo que son frecuentes los abrevaderos; y con el uso del agua para fines domésticos, como es el caso de los lavaderos. Finalmente, los sistemas mixtos, que captan los recursos de distintas formas: azud y fuente (o foggara); fuente y foggara; y fuente y pozo. Es decir, con cierta frecuencia, se combinan aguas superficiales con recursos subterráneos. Los elementos asociados a estos sistemas conforman conjuntos, muchos de ellos, patrimoniales. La longitud y la superficie que comprenden es variable, pero por lo general no son sistemas tan limitados como los de manantiales. Entre los riegos más importantes generados por morfologías mixtas de captaciones destacan el riego de Altea la Vella, cuya captación se realiza a través de un azud y tres fuentes (la principal es la Font Gran).

Los sistemas de riego más destacados corresponden a los municipios de la cuenca baja. Nos referimos a Callosa d'en Sarrià (29,4\% del regadío de 1956) y Altea $(24,6 \%)$, seguidos por La Nucia y Polop de la Marina; los cuatro representan el 79,5\% de la superficie bonificada. Los municipos de la cuenca alta alcanzan el 20,5\% de las 1.505 Ha alumbradas: Benimantell (4\%), Confrides $(3,4 \%)$ y Beniardà $(3,2 \%)$.

Los cultivos tradicionales en la cuenca del Guadalest-Algar han sido la viña en las áreas de secano, para la elaboración de pasas y en menor medida para la vinivicación, y en las zonas de regadío hortalizas y cereales. Cultivos que fueron sustituyéndose por otros más rentables, fruto de la imposición de las pautas de la agricultura comercial. En el secano, destacan los olivos, almendros y frutales de secano; en las áreas irrigadas han proliferado los frutales como el níspero. Este cultivo fue introducido en la Península Ibérica por el botánico callosino Juan Bautista Berenguer en el siglo XIX, y se ha convertido en la principal producción de la zona (alrededor de 1.000 hectáreas), acompañada de los cítricos entre los que existe una cierta dualidad entre los naranjos y los limoneros, mientras que las hortalizas han quedado reducidas a pequeños rodales para el autoconsumo. Además en los últimos años se han introducido nuevas variedades frutales como son los aguacateros o los chirimoyos que aprovechan las temperaturas suaves de la zona y así como una suficiente disponibilidad hídrica.

\section{Los elementos de los sistemas de riego del Algar-Guadalest}

En la cuenca del Guadalest-Algar se han identificado alrededor de 120 sistemas de riego, la inmensa mayoría de ellos se encuentran funcionales y sólo un reducido porcentaje se encuentra no activos o desaparecidos. De los 120 sistemas 
Cuadro 1. Comparativa de superficies de riego en los años 1956 y 2008

\begin{tabular}{|l|c|c|c|c|}
\hline \multicolumn{1}{|c|}{ Municipios } & $\begin{array}{c}\text { Sup. de regadío } \\
\text { año 1956 (ha) }\end{array}$ & $\begin{array}{c}\text { Sup. de regadío } \\
\text { año 2008 (ha) }\end{array}$ & $\begin{array}{c}\text { Sup. de regadío } \\
\text { Eventual 2008 } \\
\text { (ha) }\end{array}$ & $\begin{array}{c}\text { Diferencia año } \\
\mathbf{2 0 0 8} \mathbf{~ 1 9 5 6 ~ ( h . ) ~}\end{array}$ \\
\hline Altea & 370,48 & $1.013,71$ & 0,00 & $\mathbf{6 4 3 , 2 3}$ \\
\hline Beniardà & 48,41 & 0,16 & 36,61 & $\mathbf{- 4 8 , 2 5}$ \\
\hline Benifato & 26,86 & 0,39 & 26,10 & $\mathbf{- 2 6 , 4 7}$ \\
\hline Benimantell & 59,91 & 1,34 & 45,91 & $\mathbf{- 5 8 , 5 7}$ \\
\hline Bolulla & 39,76 & 126,20 & 0,00 & $\mathbf{8 6 , 4 4}$ \\
\hline $\begin{array}{l}\text { Callosa d'en } \\
\text { Sarrià }\end{array}$ & 443,26 & $1.492,52$ & 0,00 & $\mathbf{1 . 0 4 9 , 2 7}$ \\
\hline $\begin{array}{l}\text { Castell de } \\
\text { Guadalest }\end{array}$ & 23,57 & 31.05 & 4,20 & $\mathbf{7 , 4 8}$ \\
\hline Confrides & 51,10 & 0 & 40.88 & $\mathbf{- 5 1 , 1 0}$ \\
\hline La Nucia & 234,94 & 311,69 & 0,00 & $\mathbf{7 6 , 7 5}$ \\
\hline L'alfàs Del Pi & 41,21 & 14,47 & 0,00 & $\mathbf{- 2 6 , 7 4}$ \\
\hline $\begin{array}{l}\text { Polop de la } \\
\text { Marina }\end{array}$ & 147,59 & 363,82 & 0,00 & $\mathbf{2 1 6 , 2 3}$ \\
\hline Tàrbena & 18,30 & 7,09 & 0,00 & $\mathbf{- 1 1 , 2 1}$ \\
\hline Total & $\mathbf{1 . 5 0 5 , 4 0}$ & $\mathbf{3 . 3 6 2 , 4 5}$ & $\mathbf{1 5 3 , 6 9}$ & $\mathbf{1 . 8 5 7 , 0 5}$ \\
\hline
\end{tabular}

Fuente: elaboración propia, a partir de la foto área de 1956 y de la ortoimagen del 2008.

12 pertenecen al Algar, 27 al Guadalest, 34 a sistemas ligados a barrancos y captaciones varias, y 47 a manantiales y galerías drenantes. Se han cartografiado 238.602 metros de canales, identificados 852 elementos patrimoniales y catalogados, 159. Es reseñable su elevada funcionalidad, pues representa el $84,5 \%$ de los elementos, mientras que los no activos únicamente representan el 11,5\% y los desaparecidos no alcanzan el 4\%. Por municipios la zona costera (Altea, Callosa d'en Sarrià, La Nucia y Polop de la Marina) reúne 519 elementos patrimoniales (60,9\%); y la cuenca alta del Guadalest-Algar (Beniardà, Benifato, Benimantell, Bolulla, Castell de Guadalest, Confrides y Tàrbena), 333 elementos (39,1\%). 
Cuadro 2. Clasificación de elementos hidráulicos según su funcionalidad en los municipios del sistema Guadalest-Algar

\begin{tabular}{|l|c|c|c|c|}
\hline \multicolumn{1}{|c|}{ Municipio } & Funcional & No funcional & Desaparecido & TOTAL \\
\hline Altea & 176 & 47 & 6 & $\mathbf{2 2 9}$ \\
\hline Beniardà & 25 & 4 & 5 & $\mathbf{3 4}$ \\
\hline Benifato & 15 & 8 & 2 & $\mathbf{2 5}$ \\
\hline Benimantell & 36 & 9 & 1 & $\mathbf{4 6}$ \\
\hline Bolulla & 19 & 1 & 0 & $\mathbf{2 0}$ \\
\hline Callosa d'en Sarrià & 152 & 3 & 2 & $\mathbf{1 5 7}$ \\
\hline Castell de Guadalest & 46 & 11 & 3 & $\mathbf{6 0}$ \\
\hline Confrides & 60 & 5 & 8 & $\mathbf{7 3}$ \\
\hline La Nucia & 53 & 0 & 2 & $\mathbf{5 5}$ \\
\hline Polop de la Marina & 73 & 2 & 3 & $\mathbf{7 8}$ \\
\hline Tàrbena & 65 & 8 & 2 & $\mathbf{7 5}$ \\
\hline TOTAL & $\mathbf{7 2 0}$ & $\mathbf{9 8}$ & $\mathbf{3 4}$ & $\mathbf{8 5 2}$ \\
\hline
\end{tabular}

Fuente: elaboración propia

La naturaleza de los elementos analizados así como la forma de asociarse entre ellos, generando conjuntos patrimoniales en algunos casos, permiten diferenciar una zonificación en la cuenca del Guadalest-Algar. De hecho se diferencian dos zonas. Por una parte, el sector del interior, más montañoso, donde son más frecuentes los conjuntos patrimoniales integrados por varios elementos. Destacan los conjuntos de fuente y balsa; fuente, abrevadero y lavadero; o los de fuente, abrevadero, lavadero y balsa. Por otra parte, en el sector litoral o en sistemas de mayores dimensiones, abundan más los elementos individuales, entre los que destacan por su número los azudes, los acueductos o los minados.

La cuenca de los ríos Guadalest-Algar es especialmente rica en elementos hidráulicos. Se han identificado 852. Destaca su elevado índice de funcionalidad, próximo al $85 \%$, mientras que los no activos representan el 11\% y los desaparecidos el restante $4 \%$. Una proporción mínima si la comparamos con territorios vecinos como la cuenca del Gorgos-Xaló. La tipología más frecuente corresponde a los elementos de acumulación, que representan el 37,1\% (balsas); los de captación representan el 27,6\% (azudes, fuentes y foggaras); a continuación los de transporte, 13,8\% (acueductos, sifones y minados); los de distribución, el $12 \%$; y finalmente los de uso (abrevaderos, lavaderos o gallipuentes, entre otros), el 9,5\%. La alberca es el elemento más presente alcanzando el número de 315, 266 de las cuales, el 37\%, están funcionales. Le siguen en número las fuentes, los partidores y los azudes. 
Cuadro 3. Identificación de los elementos hidráulicos del sistema Algar-Guadalest

\begin{tabular}{|l|c|c|c|c|}
\hline Elemento & Funcional & No funcional & Desaparecido & TOTAL \\
\hline Abrevadero & 11 & 3 & 2 & $\mathbf{1 6}$ \\
\hline Acueducto & 37 & 5 & 5 & $\mathbf{4 7}$ \\
\hline Azud & 53 & 6 & 9 & $\mathbf{6 8}$ \\
\hline Balsa & 266 & 45 & 4 & $\mathbf{3 1 5}$ \\
\hline Depósito & 0 & 1 & 0 & $\mathbf{1}$ \\
\hline Derramador & 1 & 1 & 0 & $\mathbf{2}$ \\
\hline Foggara & 27 & 1 & 1 & $\mathbf{2 9}$ \\
\hline Fuente & 108 & 6 & 0 & $\mathbf{1 1 4}$ \\
\hline Gallipuente & 2 & 0 & 0 & $\mathbf{2}$ \\
\hline Lavadero & 18 & 4 & 6 & $\mathbf{2 8}$ \\
\hline Losa de lavado & 28 & 2 & 0 & $\mathbf{3 0}$ \\
\hline Mina* & 32 & 4 & 0 & $\mathbf{3 6}$ \\
\hline Molineta & 1 & 1 & 0 & $\mathbf{2}$ \\
\hline Motor & 14 & 3 & 2 & $\mathbf{1 9}$ \\
\hline Noria & 0 & 2 & 1 & $\mathbf{3}$ \\
\hline Partidor & 93 & 9 & 3 & $\mathbf{1 0 5}$ \\
\hline Sifón* & 29 & 5 & 1 & $\mathbf{3 5}$ \\
\hline TOTAL & $\mathbf{7 2 0}$ & $\mathbf{9 8}$ & $\mathbf{3 4}$ & $\mathbf{8 5 2}$ \\
\hline
\end{tabular}

Identificación de los sistemas de regadio históricos de la cuenca AlgarGuadalest

La atomización de los sistemas de regadío es un rasgo común de los regadíos tradicionales de las cuencas mediterráneas de la Marina. Como acontece en la cuenca del Gorgos, Girona o Amadorio, son muy abudantes los regadíos que se extienden por la cuenca del Algar-Guadalest. De los numerosos sistemas identificados, 36 corresponden a las aguas fluviales del Guadalest, y otros 17 a las del Algar; 54, de barrancos y policaptaciones; y 93, de fuentes, manantiales, pozos históricos y galerías drenantes. En los cuadros adjuntos se procede a su identificación y caracterización. 


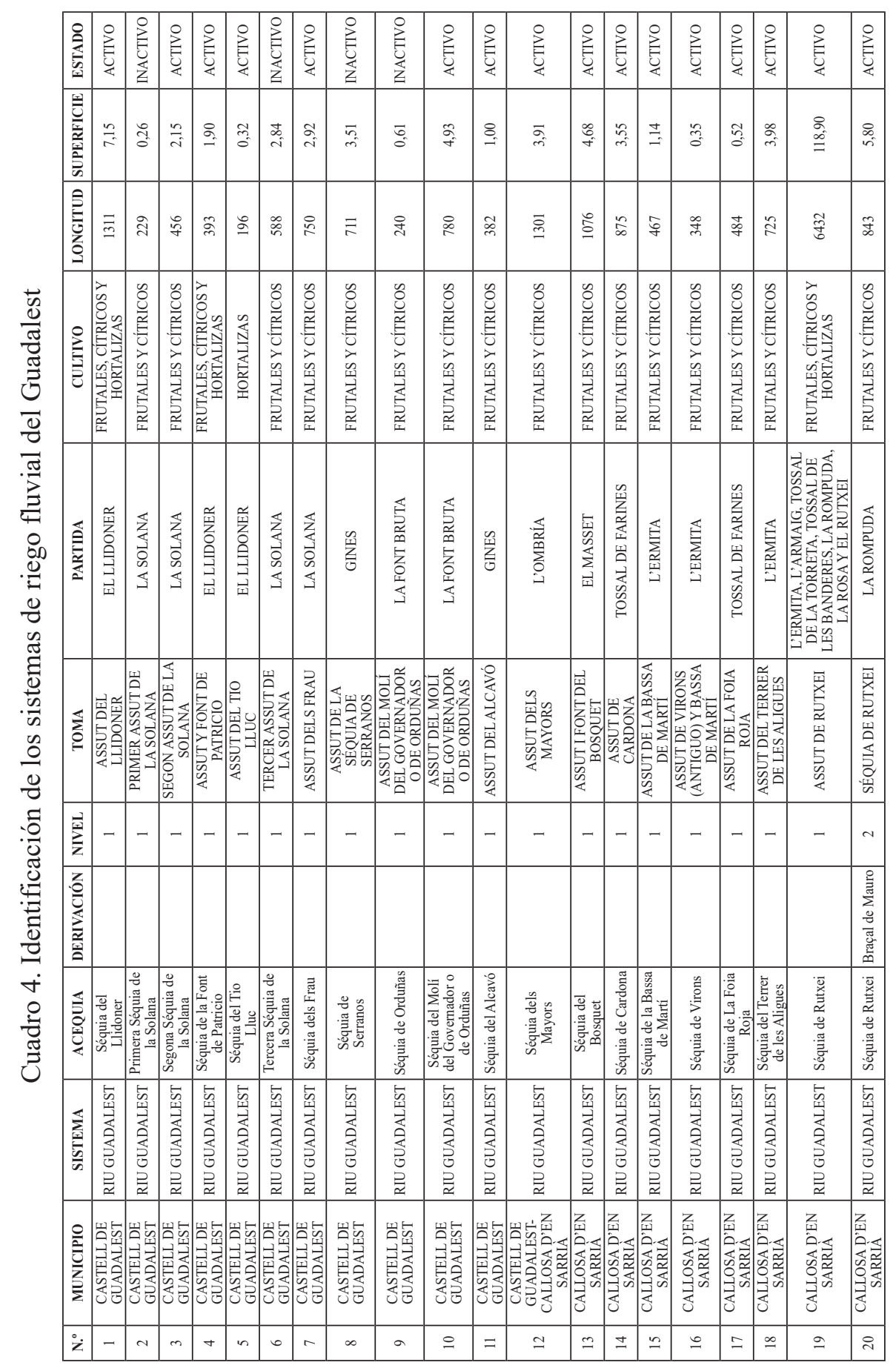




\begin{tabular}{|c|c|c|c|c|c|c|c|c|c|c|c|c|c|c|c|c|}
\hline 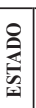 & 总 & 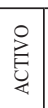 & 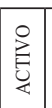 & 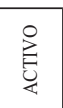 & 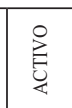 & 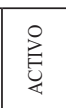 & 龸 & 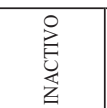 & 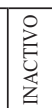 & 总 & 离 & 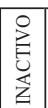 & 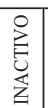 & 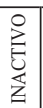 & 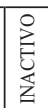 & 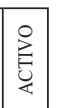 \\
\hline 폴 & $\begin{array}{l}\circ \\
\stackrel{2}{2}\end{array}$ & $\underset{工}{-}$ & जे & $\begin{array}{l}5 \\
\text { o }\end{array}$ & $\begin{array}{c}\text { लि } \\
\text { के }\end{array}$ & $\begin{array}{l}\text { nิ } \\
\text { iे }\end{array}$ & $\begin{array}{l}\vec{\lambda} \\
\vec{d}\end{array}$ & $\begin{array}{l}\widetilde{\sigma} \\
\stackrel{0}{=}\end{array}$ & 悉 & $\begin{array}{l}\infty \\
\substack{\infty \\
\text { i }}\end{array}$ & $\stackrel{g}{g}$ & $\begin{array}{l}R \\
f \\
f\end{array}$ & $\begin{array}{l}\simeq \\
=\end{array}$ & 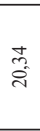 & $\begin{array}{l}\vec{F} \\
\text { 足 }\end{array}$ & 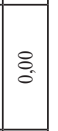 \\
\hline כ) & हี & 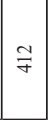 & s & 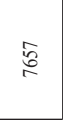 & 总 & 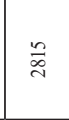 & ڤ્สิ & 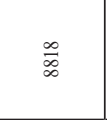 & 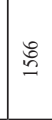 & $\stackrel{\infty}{\Theta}$ & $\overrightarrow{\stackrel{\infty}{~}}$ & ถू & $\stackrel{\circ}{=}$ & है & 8 & $\therefore$ \\
\hline לְ. & 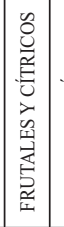 & 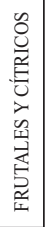 & 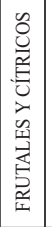 & 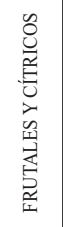 & 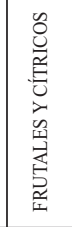 & 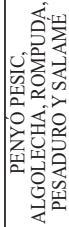 & 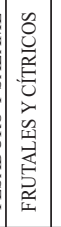 & 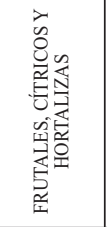 & 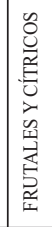 & 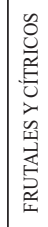 & 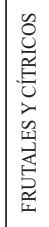 & 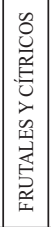 & 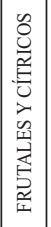 & 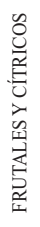 & 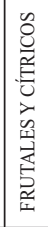 & 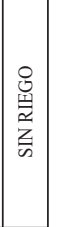 \\
\hline 彥 & 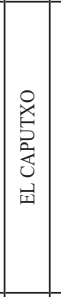 & 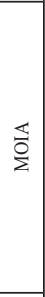 & 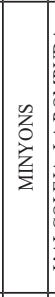 & 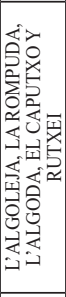 & 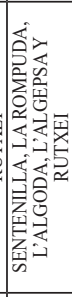 & 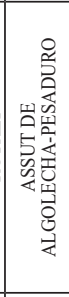 & 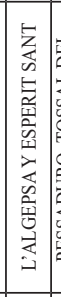 & 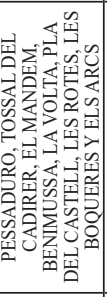 & 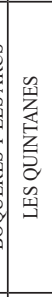 & 蓄 & 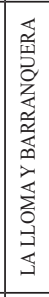 & 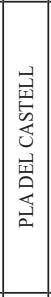 & 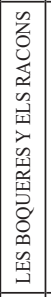 & 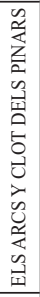 & 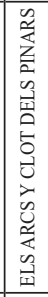 & 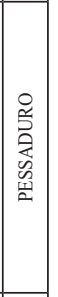 \\
\hline$\sum_{0}^{\frac{\pi}{2}}$ & 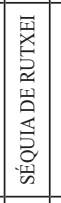 & 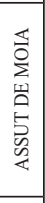 & 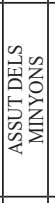 & 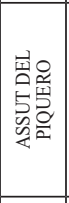 & 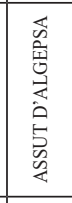 & 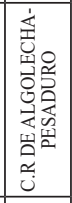 & 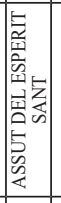 & 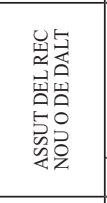 & 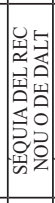 & & & 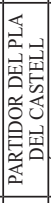 & 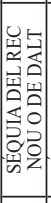 & 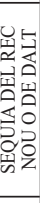 & 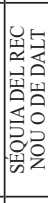 & 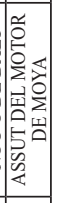 \\
\hline$\frac{\vec{x}}{\mathrm{x}}$ & N & - & - & - & - & - & - & - & $\mathrm{N}$ & N & 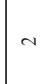 & 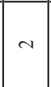 & $\mathrm{N}$ & N & $\alpha$ & - \\
\hline $\begin{array}{l}z \\
0 \\
0 \\
0 \\
0 \\
0 \\
0 \\
0\end{array}$ & 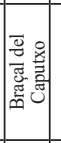 & & & & & & & & 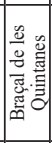 & 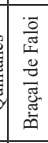 & 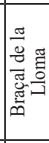 & 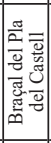 & 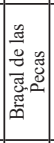 & 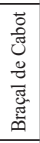 & 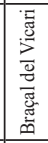 & \\
\hline 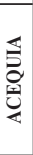 & 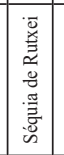 & & 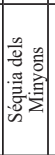 & 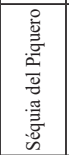 & 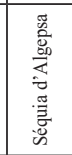 & 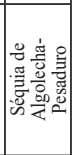 & 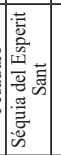 & 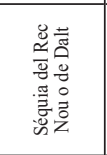 & 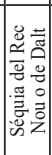 & 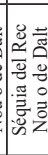 & & 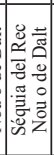 & 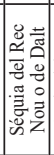 & & 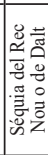 & 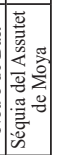 \\
\hline $\begin{array}{l}\frac{\pi}{2} \\
\frac{1}{2} \\
\frac{2}{n}\end{array}$ & 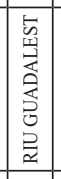 & 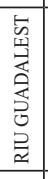 & 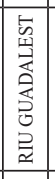 & 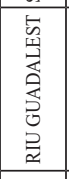 & 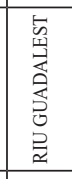 & 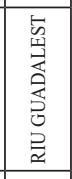 & 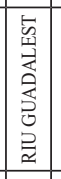 & 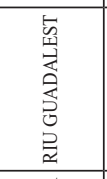 & 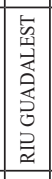 & 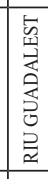 & 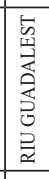 & 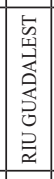 & 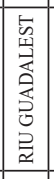 & 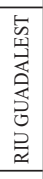 & 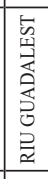 & 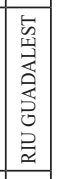 \\
\hline 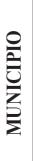 & 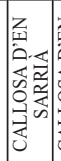 & 5 & 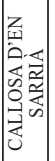 & 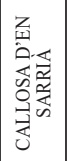 & 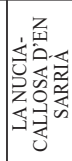 & 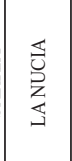 & 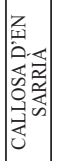 & 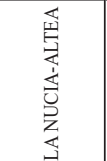 & 画 & 画 & 画 & 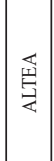 & 薑 & 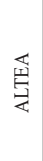 & 䅦 & 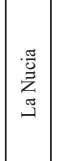 \\
\hline ¿̇ & $\vec{\lambda}$ & $\pi$ & $\approx$ & $\ddot{d}$ & $\approx$ & $\stackrel{\sim}{\circ}$ & $\bar{A}$ & $\stackrel{\sim}{\text { I }}$ & নి & 同 & $\vec{m}$ & $\approx$ & $\approx$ & 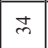 & $\approx$ & i \\
\hline
\end{tabular}




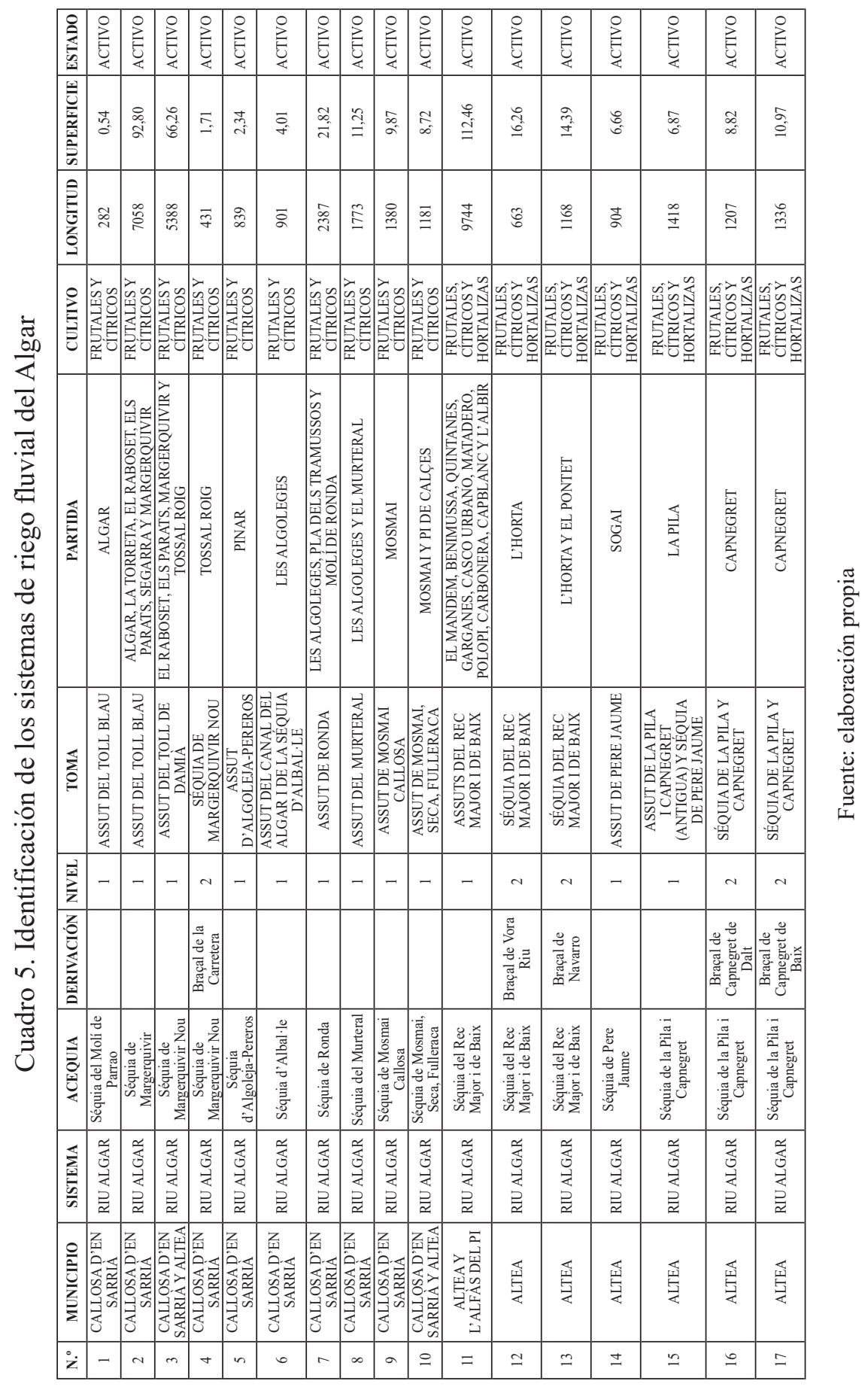




\begin{tabular}{|c|c|c|c|c|c|c|c|c|c|c|c|c|c|c|c|c|c|c|c|c|}
\hline 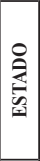 & 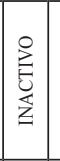 & 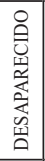 & 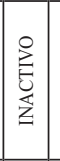 & 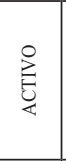 & 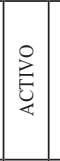 & $\mid$\begin{tabular}{l}
0 \\
$\grave{Z}$ \\
\hdashline
\end{tabular} & 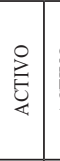 & 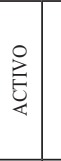 & 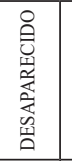 & 龸 & 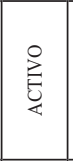 & 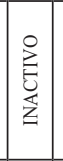 & 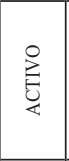 & 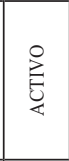 & 㟒 & 娄 & 亚 & 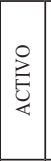 & 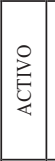 & 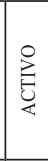 \\
\hline 玨 & वे & 命 & $\underset{c}{t}$ & مh & : & $\Rightarrow$ & $\begin{array}{l}\vec{n} \\
\stackrel{\Omega}{\Omega}\end{array}$ & $\Xi$ & $\stackrel{\vec{m}}{\stackrel{2}{r}}$ & $\begin{array}{l}8 \\
\ddot{3}\end{array}$ & $\begin{array}{l}\stackrel{2}{i} \\
\text { in }\end{array}$ & 我 & $\stackrel{\substack{+\leftarrow}}{ }$ & $\begin{array}{l}F \\
\text { fus }\end{array}$ & 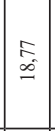 & $\stackrel{\infty}{\sim}$ & 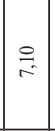 & $\underset{m}{f}$ & $\begin{array}{l}0 \\
i \\
i\end{array}$ & 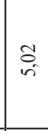 \\
\hline $\begin{array}{l}0 \\
0 \\
0 \\
0 \\
0\end{array}$ & 题 & ते & के & 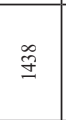 & $\vec{n}$ & in & 莡 & तี & 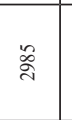 & क్రి & 今్ & 文 & సิ & $\stackrel{\infty}{\stackrel{\infty}{ \pm}}$ & 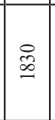 & $\tilde{F}$ & $\stackrel{\circ}{\circ}$ & ลี & $\bar{\ddagger}$ & $\tilde{B}$ \\
\hline 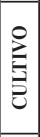 & 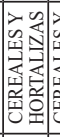 & 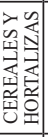 & 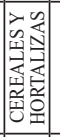 & 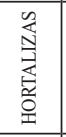 & 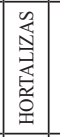 & 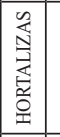 & 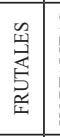 & 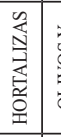 & 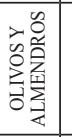 & 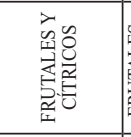 & 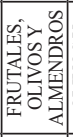 & 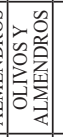 & 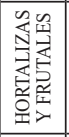 & 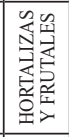 & 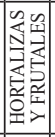 & 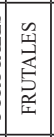 & 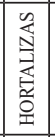 & 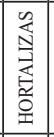 & 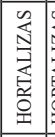 & 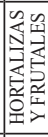 \\
\hline 产 & 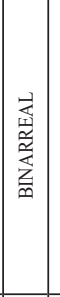 & 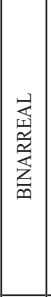 & 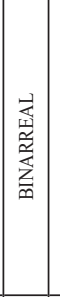 & 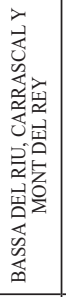 & 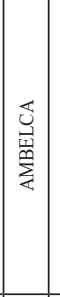 & 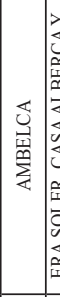 & 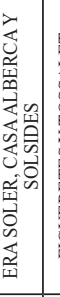 & 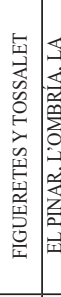 & 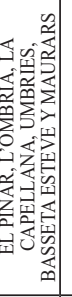 & 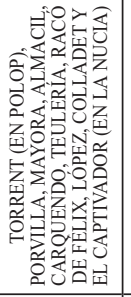 & 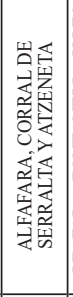 & 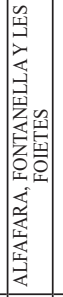 & 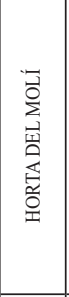 & 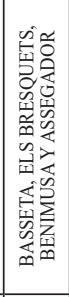 & 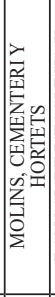 & 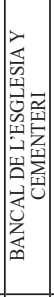 & $\begin{array}{l}8 \\
\text { 章 } \\
\text { 至 } \\
\text { ت }\end{array}$ & 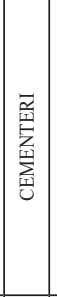 & 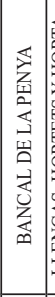 & 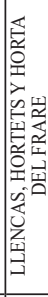 \\
\hline ְ. & 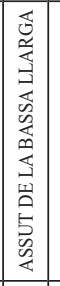 & 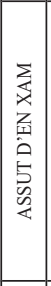 & 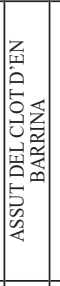 & 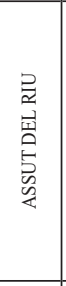 & 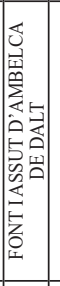 & 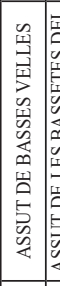 & 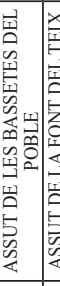 & 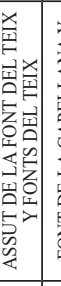 & 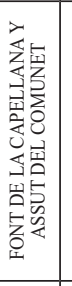 & 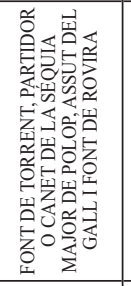 & 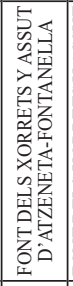 & 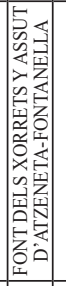 & 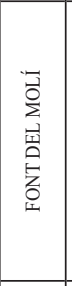 & 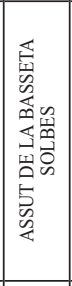 & 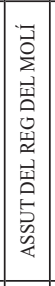 & 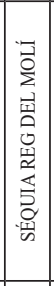 & 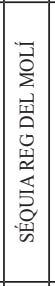 & 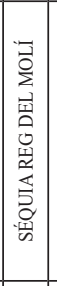 & 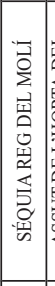 & 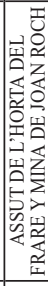 \\
\hline$\frac{1}{Z}$ & - & - & - & - & - & - & - & - & - & - & - & - & - & - & - & $\sim$ & N & $\sim$ & $\sim$ & - \\
\hline בֶ & & & & & & & & & & & & & & & & 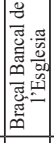 & 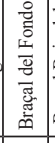 & & & \\
\hline 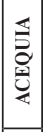 & 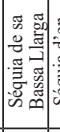 & : & 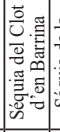 & 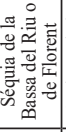 & 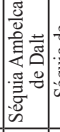 & 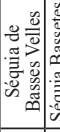 & 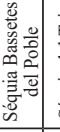 & 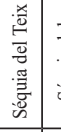 & 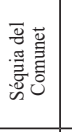 & 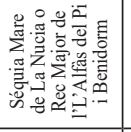 & 舀㺃 & 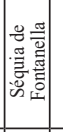 & 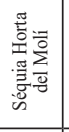 & 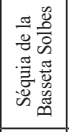 & 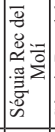 & 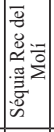 & & 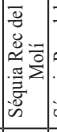 & 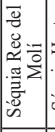 & 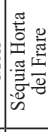 \\
\hline 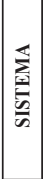 & 崖 & 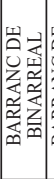 & 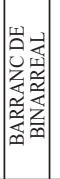 & 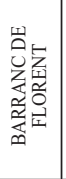 & 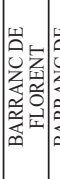 & 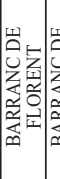 & 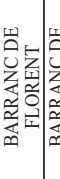 & 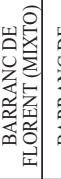 & 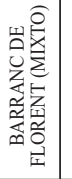 & 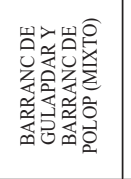 & 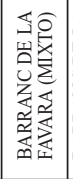 & 过国 & 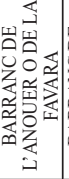 & 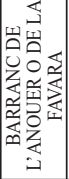 & & 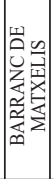 & & & & 罢 \\
\hline 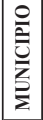 & 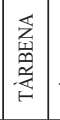 & 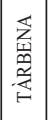 & 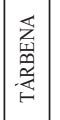 & 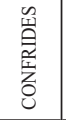 & $\begin{array}{l}\text { 留 } \\
\text { 善 } \\
\text { 喕 }\end{array}$ & 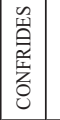 & 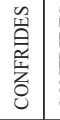 & $\begin{array}{l}\text { 留 } \\
\text { 鳏 } \\
\text { 总 } \\
\end{array}$ & 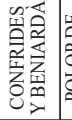 & 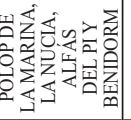 & 黄 & 量 & 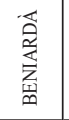 & 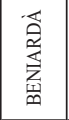 & 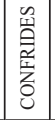 & \begin{tabular}{|l|} 
\\
㽞 \\
爰 \\
兽 \\
\end{tabular} & 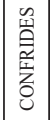 & 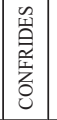 & 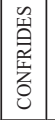 & 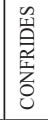 \\
\hline$\ddot{z}$ & -1 & $\sim \mid$ & $m$ & $\nabla$ & in & 0 & $r$ & $\infty$ & $a$ & $\stackrel{\circ}{\circ}$ & $=$ & $\simeq$ & 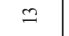 & \pm & $\because$ & 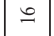 & $=$ & $\simeq$ & 9 & สิ \\
\hline
\end{tabular}




\begin{tabular}{|c|c|c|c|c|c|c|c|c|c|c|c|c|c|c|c|c|c|c|c|}
\hline 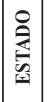 & 总 & 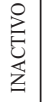 & 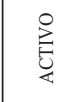 & 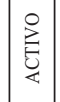 & 离 & 总 & 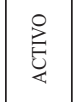 & 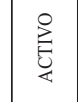 & 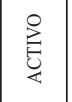 & 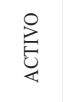 & 总 & 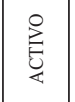 & 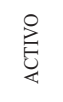 & $\stackrel{0}{\gtrless}$ & 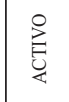 & 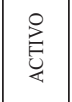 & 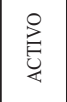 & 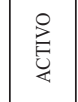 & 莺 \\
\hline 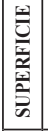 & సू. & $\stackrel{8}{\circ}$ & $\begin{array}{l}\text { ch } \\
\stackrel{m}{g}\end{array}$ & $\vec{\therefore}$ & \begin{tabular}{|l}
$\vec{n}$ \\
$\stackrel{5}{0}$
\end{tabular} & $\stackrel{3}{-1}$ & 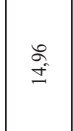 & $\stackrel{\infty}{~}$ & $\stackrel{m}{\circ}$ & $\overrightarrow{\mathrm{I}}$ & 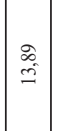 & लె & $\begin{array}{l}\mathscr{\infty} \\
\stackrel{m}{m}\end{array}$ & $\begin{array}{l}\infty \\
\stackrel{\infty}{\infty} \\
\stackrel{2}{9}\end{array}$ & $\stackrel{n}{\stackrel{n}{n}}$ & $\begin{array}{l}\stackrel{8}{\mathrm{I}} \\
\stackrel{1}{2}\end{array}$ & $\stackrel{\infty}{\vec{i}}$ & वे & $\begin{array}{l}\text { की } \\
\text { ते }\end{array}$ \\
\hline 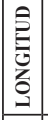 & $\stackrel{ \pm}{ \pm}$ & 嵒 & 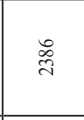 & $\overrightarrow{\mathrm{g}}$ & 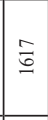 & $\tilde{\xi}$ & छे & $\stackrel{尺}{\Sigma}$ & 点 & 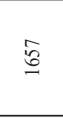 & $\stackrel{n}{r}$ & స్ & 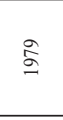 & 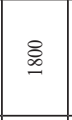 & त् & 志 & $\hat{\underline{6}}$ & 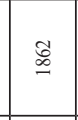 & $\frac{O}{9}$ \\
\hline 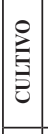 & 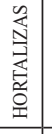 & 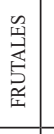 & 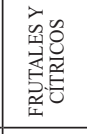 & 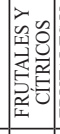 & 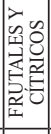 & 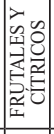 & 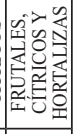 & 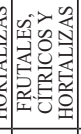 & 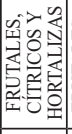 & 结 & 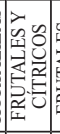 & & 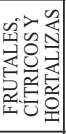 & 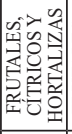 & $\begin{array}{l}1 \\
4 \\
3\end{array}$ & 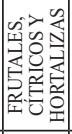 & 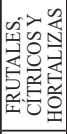 & 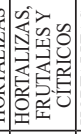 & 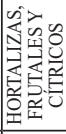 \\
\hline 玄 & $\begin{array}{l}\text { 鯆 } \\
\text { 舅 }\end{array}$ & 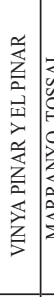 & 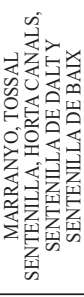 & : & 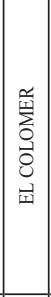 & 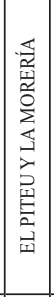 & 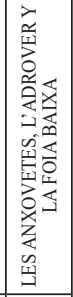 & $\underset{\Xi}{\overleftrightarrow{G}}$ & 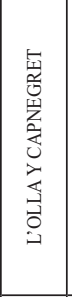 & 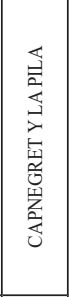 & 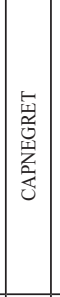 & 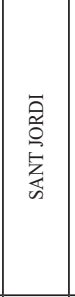 & 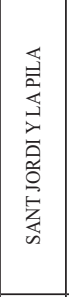 & 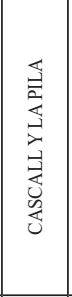 & 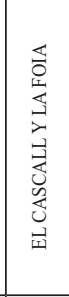 & 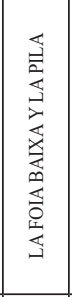 & 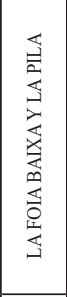 & 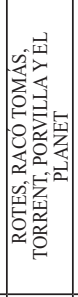 & 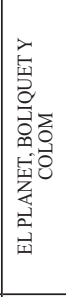 \\
\hline$\sum_{0}^{\frac{\pi}{0}}$ & 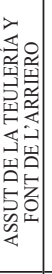 & 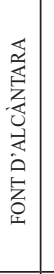 & 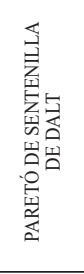 & 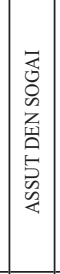 & 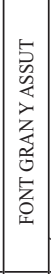 & 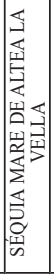 & 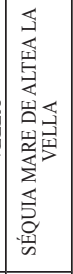 & 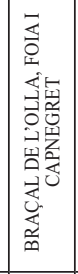 & 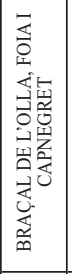 & 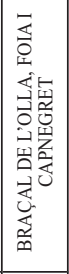 & 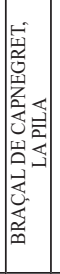 & 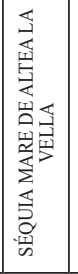 & 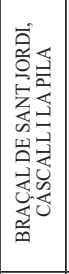 & 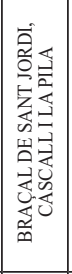 & 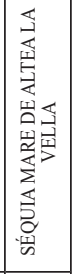 & 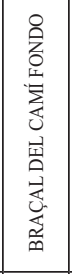 & 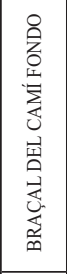 & 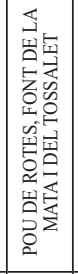 & 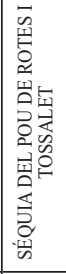 \\
\hline $\begin{array}{l}\overrightarrow{0} \\
\frac{1}{2} \\
\end{array}$ & - & - & - & - & - & $\sim$ & N & $m$ & $m$ & $m$ & $\sigma$ & $\sim$ & $m$ & $m$ & $\sim$ & $m$ & $m$ & - & $\sim$ \\
\hline 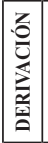 & & & & & & 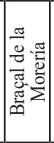 & 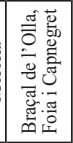 & 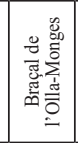 & 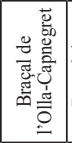 & & 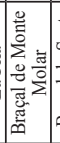 & 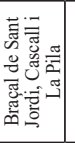 & 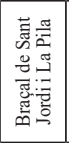 & 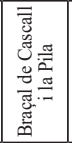 & 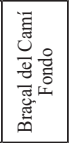 & 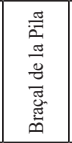 & 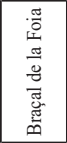 & & 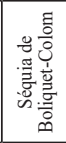 \\
\hline 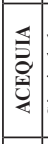 & 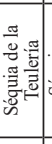 & $\mid$ & 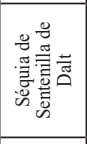 & 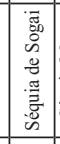 & 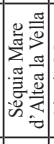 & 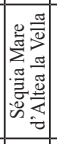 & 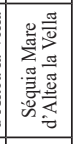 & 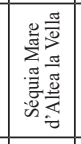 & 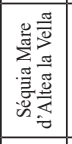 & 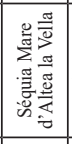 & 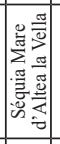 & 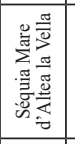 & 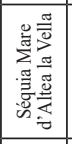 & 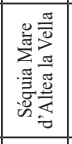 & 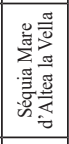 & 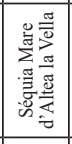 & 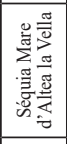 & 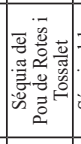 & 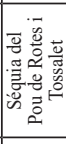 \\
\hline 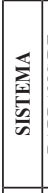 & 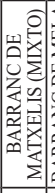 & 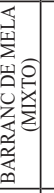 & 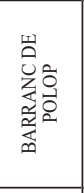 & 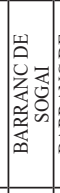 & 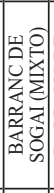 & 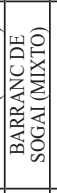 & 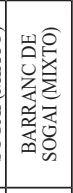 & 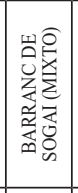 & 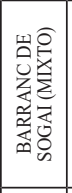 & 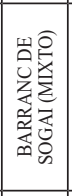 & 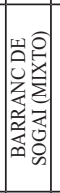 & 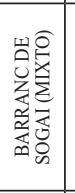 & 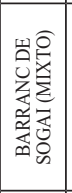 & 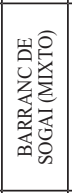 & 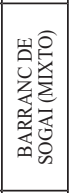 & 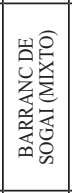 & 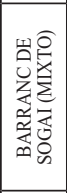 & 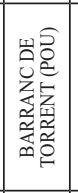 & 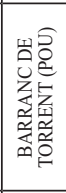 \\
\hline 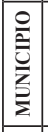 & 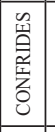 & 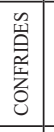 & 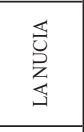 & 画 & \begin{tabular}{|l|} 
\\
襾 \\
\end{tabular} & 焉 & 画 & 壱 & 罡 & 學 & 郅 & 画 & 䓛 & 㺼 & 画 & 画 & 崫 & 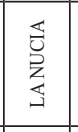 & 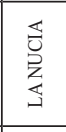 \\
\hline \begin{tabular}{l|l} 
\\
$\dot{z}$
\end{tabular} & $\overrightarrow{\mid} \mid \vec{T}$ & $\pi$ & $\pi$ & $\stackrel{\Delta}{+}$ & $\approx$ & i & i & $\stackrel{\infty}{\sim}$ & ते & 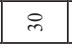 & $\vec{m}$ & $\approx$ & 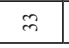 & d & $\approx$ & 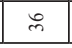 & m & $\infty$ & ले \\
\hline
\end{tabular}




\begin{tabular}{|c|c|c|c|c|c|c|c|c|c|c|c|c|c|c|c|}
\hline 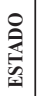 & 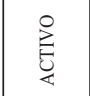 & 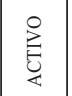 & 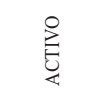 & 莣 & 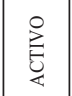 & 冚 & 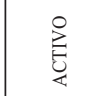 & 总 & 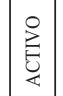 & 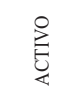 & 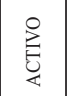 & 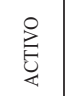 & 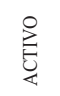 & 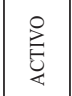 & 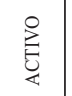 \\
\hline 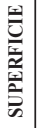 & $\begin{array}{l}\stackrel{a}{\infty} \\
\stackrel{=}{=}\end{array}$ & $\begin{array}{l} \pm \\
\stackrel{t}{0}\end{array}$ & के & 杀 & त् & : & جُ & $\begin{array}{l}\text { nू } \\
\text { ते }\end{array}$ & $\stackrel{0}{=}$ & $\begin{array}{l}\vec{m} \\
m \\
m\end{array}$ & $\underset{+}{\overrightarrow{0}}$ & $\begin{array}{l}\text { E } \\
\text { of }\end{array}$ & $\stackrel{\mathbb{Z}}{\mathrm{d}}$ & $\stackrel{\infty}{m}$ & $\underset{f}{\mathcal{f}}$ \\
\hline 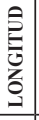 & f & $\check{0}$ & สี & f & $\stackrel{\square}{\dddot{I}}$ & $\Xi$ & 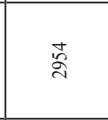 & $\stackrel{n}{\infty}$ & คे & శ్లి & đ్ & 壳 & ले & కి & 完 \\
\hline |̇. & 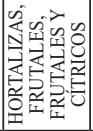 & 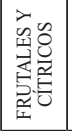 & 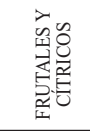 & 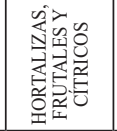 & 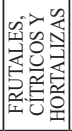 & 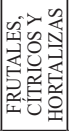 & 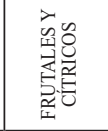 & 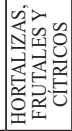 & 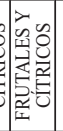 & 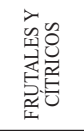 & 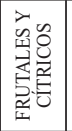 & 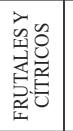 & 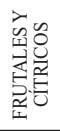 & 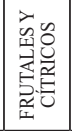 & 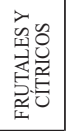 \\
\hline 彥 & 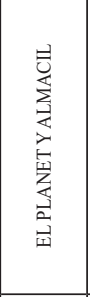 & 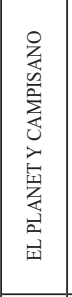 & $\begin{array}{l}\text { 崽 } \\
\text { 紊 }\end{array}$ & 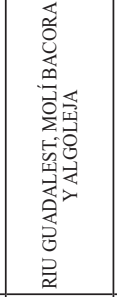 & 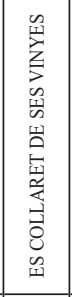 & 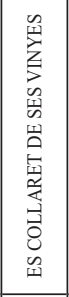 & 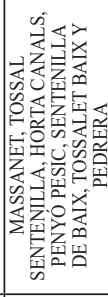 & 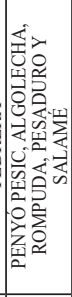 & 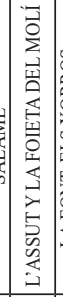 & 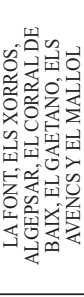 & 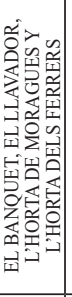 & 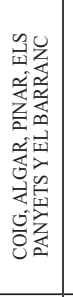 & है & 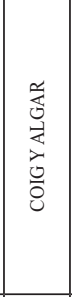 & 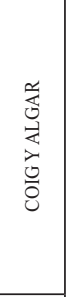 \\
\hline 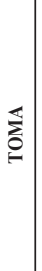 & 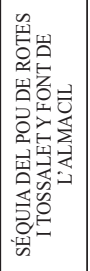 & 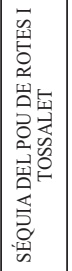 & 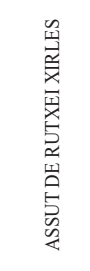 & 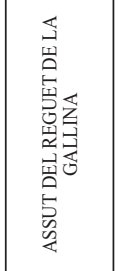 & 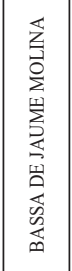 & 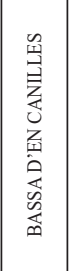 & 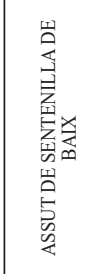 & 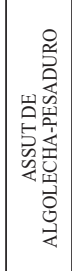 & 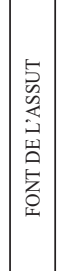 & 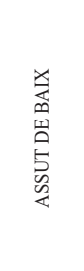 & 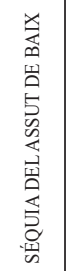 & 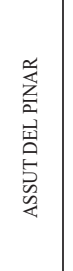 & $\begin{array}{l}0 \\
0 \\
8 \\
\text { I1 } \\
5 \\
5 \\
0 \\
0\end{array}$ & 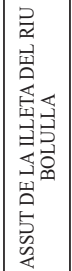 & 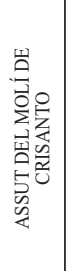 \\
\hline $\begin{array}{l}\vec{T} \\
\sum_{\bar{z}} \\
\bar{z}\end{array}$ & N & $\sim$ & - & - & - & - & - & - & - & - & $\alpha$ & - & - & - & - \\
\hline 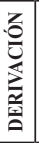 & 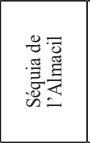 & 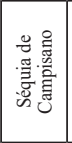 & & & & & & & & & 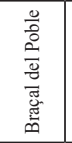 & & & & \\
\hline 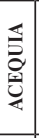 & 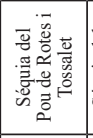 & 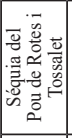 & 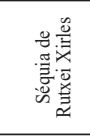 & 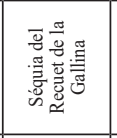 & 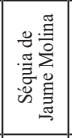 & 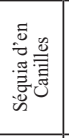 & 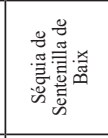 & 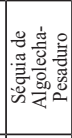 & 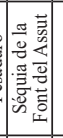 & 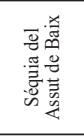 & 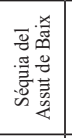 & 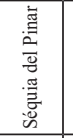 & 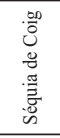 & 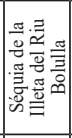 & 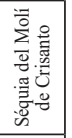 \\
\hline 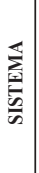 & 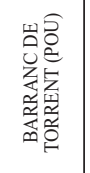 & 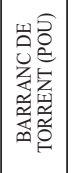 & 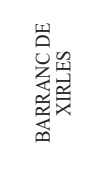 & 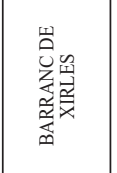 & 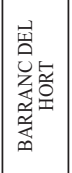 & 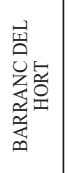 & 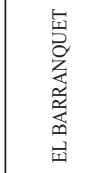 & 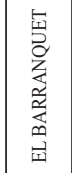 & 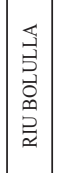 & 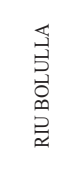 & 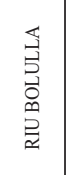 & 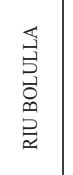 & 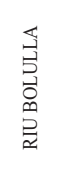 & 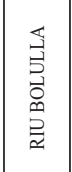 & 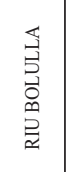 \\
\hline 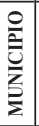 & 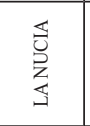 & 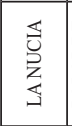 & 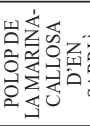 & 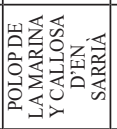 & 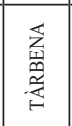 & 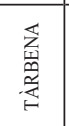 & 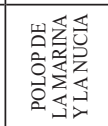 & 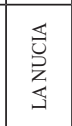 & 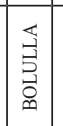 & 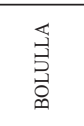 & 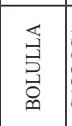 & & & 0 & 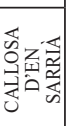 \\
\hline$\dot{z}$ & q & $F$ & F & $q$ & $\exists$ & 'f & 8 & f & $\underset{+\infty}{\infty}$ & q & in & $\bar{n}$ & in & in & in \\
\hline
\end{tabular}




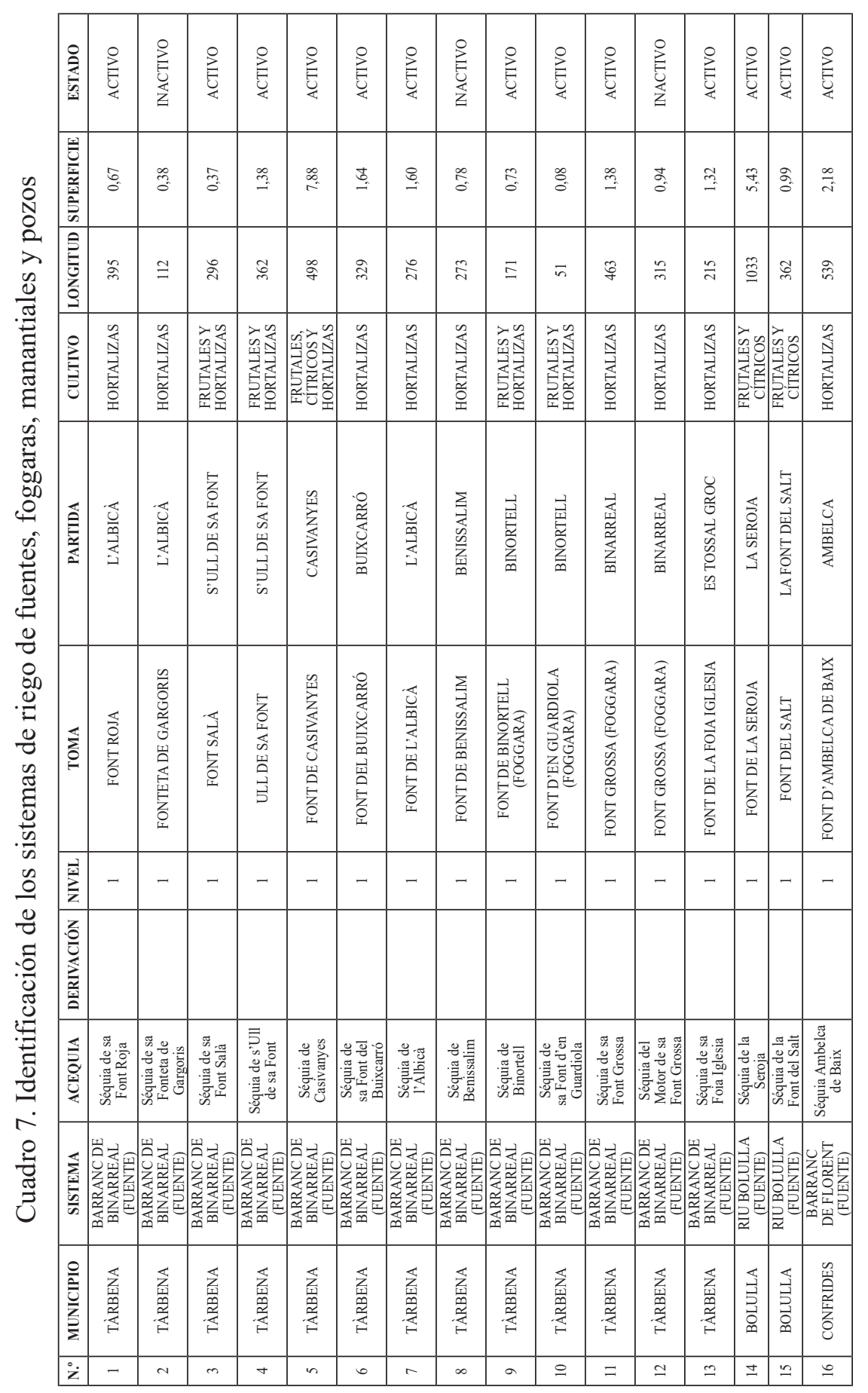




\begin{tabular}{|c|c|c|c|c|c|c|c|c|c|c|c|c|c|c|c|}
\hline$\AA$ & 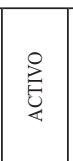 & 完 & 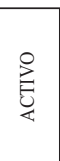 & 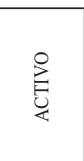 & 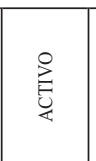 & 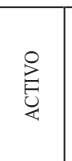 & 完 & 总 & 总 & 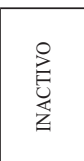 & 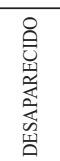 & 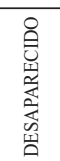 & 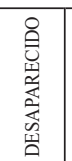 & 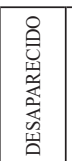 & 娄 \\
\hline 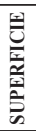 & নે & તุ. & I & $\mathrm{i}_{i}$ & $\begin{array}{l}\stackrel{n}{n} \\
\tilde{n}\end{array}$ & $\bar{n}$ & 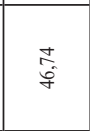 & $\begin{array}{c}\infty_{\infty}^{\infty} \\
\infty_{\infty}\end{array}$ & $\underset{\alpha}{\infty}$ & ठิ & $\begin{array}{l}\overrightarrow{\tilde{g}} \\
\stackrel{0}{1}\end{array}$ & $\stackrel{\infty}{\sim}$ & $\stackrel{\infty}{\mathfrak{i}}$ & did & fo \\
\hline f & $\stackrel{ \pm}{N}$ & $\bar{\infty}$ & 专 & $\bar{\Xi}$ & జ్ & 字 & 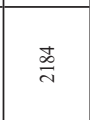 & $\tilde{\infty}$ & ฉั & 点 & F & \& & $\overline{\text { A }}$ & 表 & $\tilde{\Xi}$ \\
\hline$\sum_{0}^{\circ}$ & 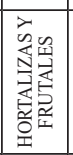 & 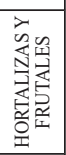 & 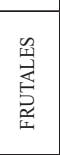 & $\begin{array}{l}\text { 串 } \\
\text { 志 } \\
\text { 总 }\end{array}$ & 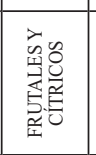 & 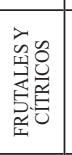 & 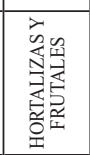 & 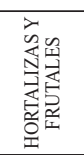 & 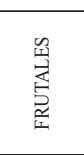 & $\begin{array}{l}\text { 嵒 } \\
\text { 焉 } \\
\text { 总 }\end{array}$ & 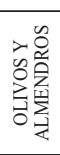 & 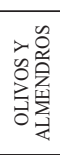 & 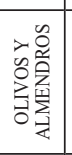 & 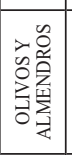 & 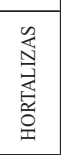 \\
\hline 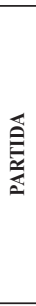 & 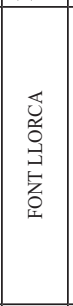 & 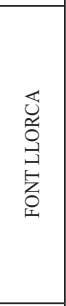 & 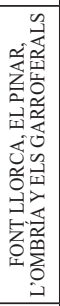 & 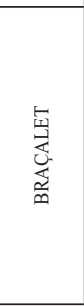 & 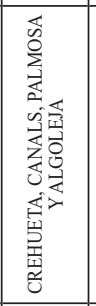 & 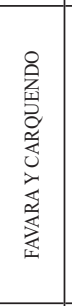 & 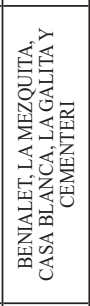 & 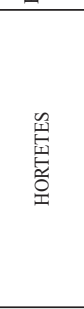 & 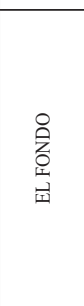 & 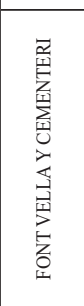 & 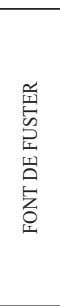 & 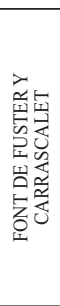 & 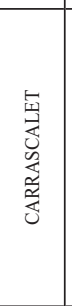 & 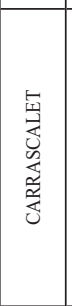 & 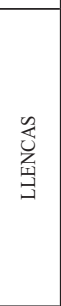 \\
\hline$\sum_{0}^{\mathbb{a}}$ & 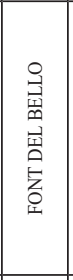 & 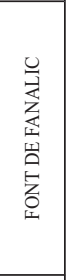 & 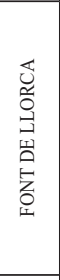 & 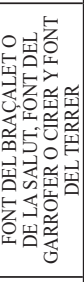 & 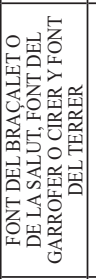 & 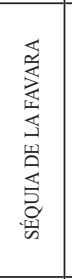 & 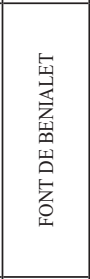 & 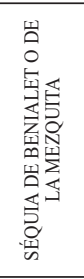 & 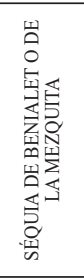 & 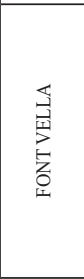 & 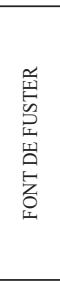 & 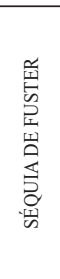 & 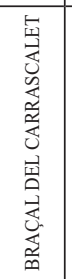 & 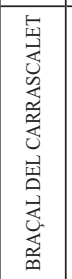 & 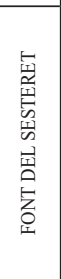 \\
\hline$\frac{1}{2}$ & _- & - & - & - & - & $m$ & - & $\sim$ & a & - & - & a & $m$ & $m$ & - \\
\hline 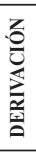 & & & & & & 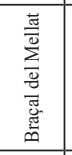 & & 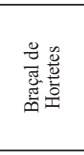 & 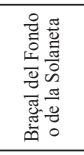 & & & 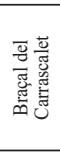 & 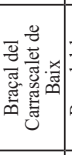 & 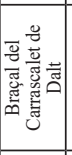 & \\
\hline 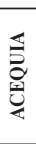 & 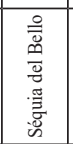 & 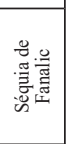 & 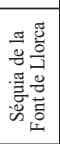 & 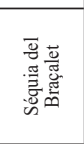 & 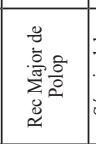 & 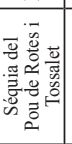 & 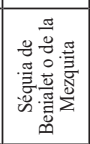 & 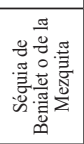 & 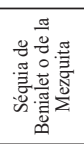 & 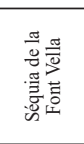 & 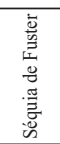 & 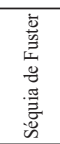 & 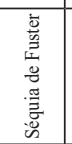 & 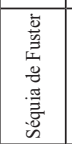 & 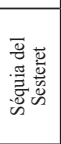 \\
\hline $\begin{array}{l}\sum_{i}^{2} \\
\frac{1}{2} \\
\frac{2}{2}\end{array}$ & 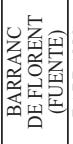 & 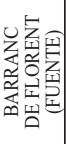 & 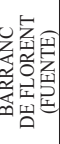 & 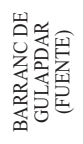 & 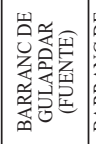 & 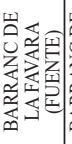 & 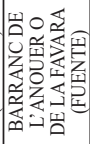 & 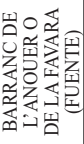 & 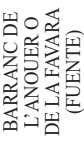 & 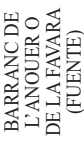 & & 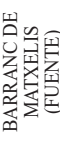 & 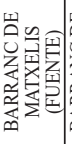 & 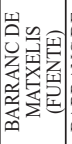 & 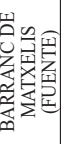 \\
\hline 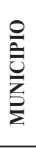 & 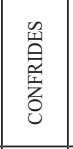 & 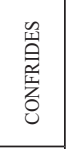 & 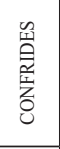 & 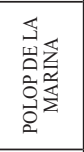 & 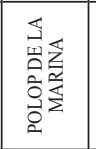 & 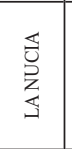 & 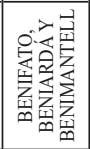 & 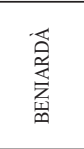 & 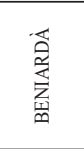 & 䓛 & 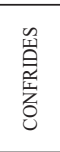 & $\begin{array}{l}\text { n } \\
\text { 留 } \\
\text { 愛 } \\
8\end{array}$ & $\begin{array}{l}\text { 留 } \\
\text { 辤 } \\
\text { 号 }\end{array}$ & 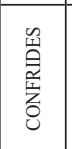 & $\begin{array}{l}\text { 留 } \\
\text { 产 } \\
\text { 苔 }\end{array}$ \\
\hline$\ddot{z}$ & $=$ & $\stackrel{\infty}{ }$ & 9 & ন & $\vec{\lambda}$ & A & $\pi$ & $\overrightarrow{4}$ & $\approx$ & $\ddot{i}$ & $\bar{\lambda}$ & $\infty_{\alpha}^{\infty}$ & ते & d & - \\
\hline
\end{tabular}




\begin{tabular}{|c|c|c|c|c|c|c|c|c|c|c|c|c|c|c|c|c|c|c|c|}
\hline 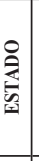 & 总 & 恖 & 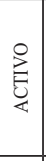 & 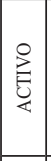 & 主 & 号 & 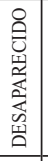 & 莺 & 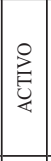 & 主 & 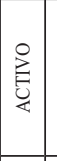 & 离 & 离 & 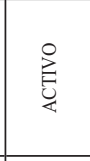 & 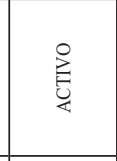 & 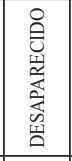 & 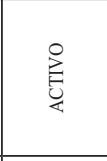 & 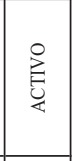 & ¿্ট \\
\hline 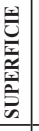 & $\mid$ & İ & స్ & 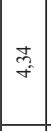 & $\begin{array}{l}\tilde{y} \\
m^{2}\end{array}$ & $\stackrel{\cong}{\cong}$ & $\begin{array}{c}\stackrel{\infty}{\infty} \\
+\end{array}$ & S్ & F & in & 8 & $\stackrel{m}{m}$ & 兽 & $\begin{array}{l}\text { त्र } \\
\infty \\
\infty\end{array}$ & : & $\equiv$ & $\underset{\infty}{\vec{\infty}}$ & @़ & $\underset{i n}{+4}$ \\
\hline 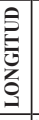 & ֻั & $\overrightarrow{\mathrm{m}}$ & तี & के & ల్ల & $\stackrel{0}{0}$ & 영 & $\stackrel{一}{\Xi}$ & in & $\stackrel{\circ}{\not}$ & $\hat{\sigma}$ & $\stackrel{\circ}{\sim}$ & $\ddot{B}$ & స్ల & $\hat{0}$ & in & 各 & 尔 & ปิ \\
\hline & & 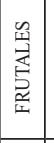 & 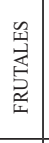 & 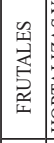 & 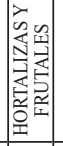 & 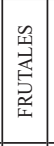 & 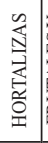 & 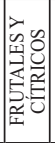 & 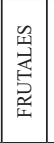 & 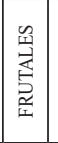 & 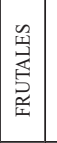 & 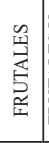 & 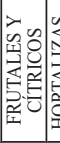 & 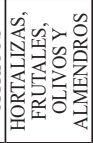 & 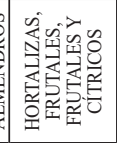 & 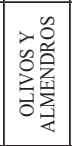 & 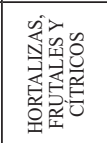 & 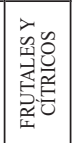 & 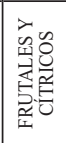 \\
\hline & 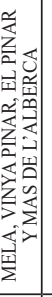 & 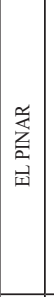 & 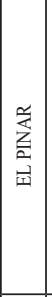 & 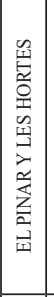 & 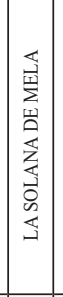 & 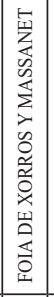 & 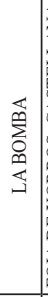 & 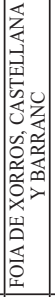 & 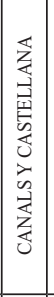 & 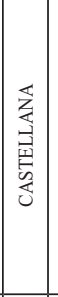 & 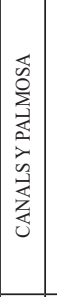 & 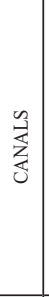 & . & 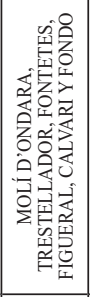 & 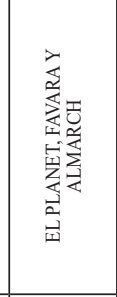 & 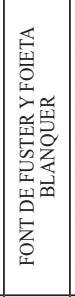 & 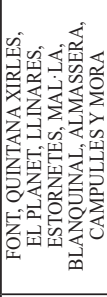 & 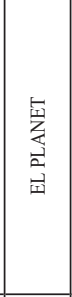 & 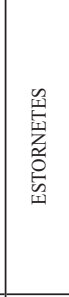 \\
\hline 茥 & 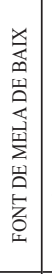 & 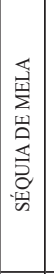 & 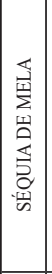 & 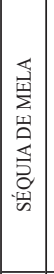 & 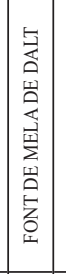 & 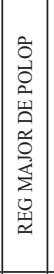 & 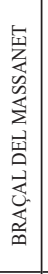 & 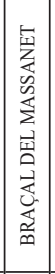 & 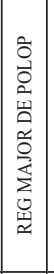 & 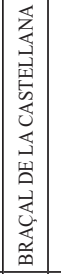 & 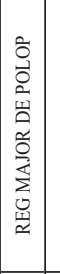 & 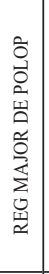 & 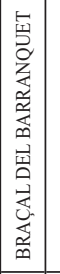 & 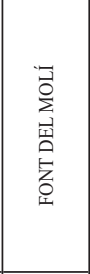 & 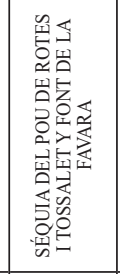 & 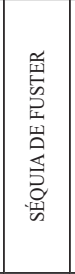 & 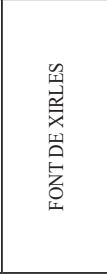 & 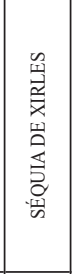 & 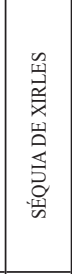 \\
\hline$\sum_{\mathbf{x}}^{-1}$ & - & $\sim$ & $\sim$ & $\sim$ & -1 & $\sim$ & m & $m$ & $\sim$ & $m$ & $\sim$ & $\sim$ & $m$ & - & $\sim$ & N & - & N & $\sim$ \\
\hline 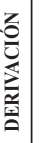 & & $\mid$ & 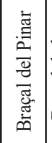 & $\mid$ & & & & & & & 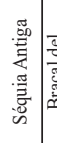 & & 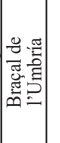 & & 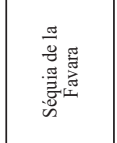 & 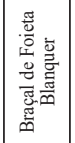 & & 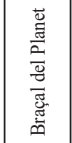 & 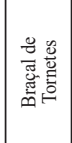 \\
\hline 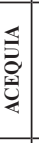 & 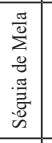 & 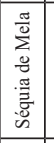 & 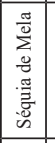 & 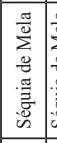 & 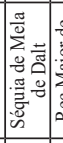 & & & & & & & 帘 & 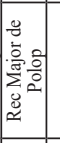 & 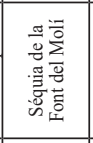 & 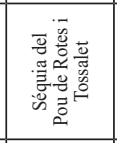 & 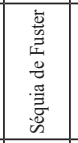 & 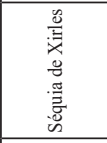 & 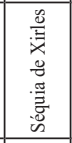 & 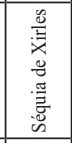 \\
\hline 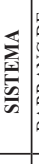 & 急 & 要国: & 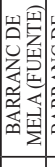 & 国图 & 象 & & & & & & & 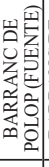 & 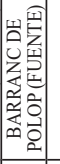 & 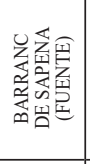 & 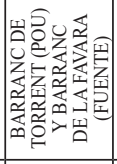 & 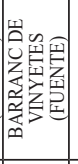 & 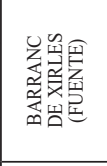 & 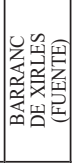 & 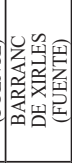 \\
\hline 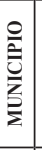 & $\begin{array}{l}\text { 壁 } \\
\text { 善 } \\
\text { 总 }\end{array}$ & 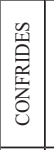 & 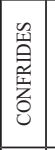 & 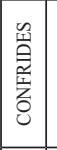 & 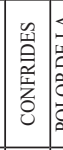 & $\approx$ & 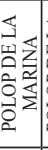 & 1 & & 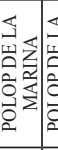 & 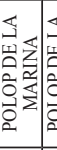 & 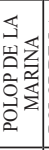 & 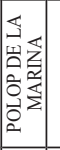 & 薦 & 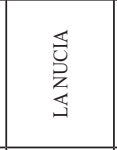 & 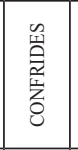 & 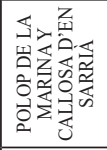 & 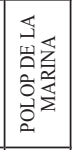 & 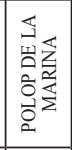 \\
\hline$\ddot{z}$ & $\approx$ & $m$ & 焉 & $\approx$ & \begin{tabular}{|l|} 
\\
\end{tabular} & n & \begin{tabular}{l|}
$\infty$ \\
$\infty$
\end{tabular} & m & \begin{tabular}{|l|}
$g$ \\
\end{tabular} & $\begin{array}{ll} \\
\end{array}$ & $\begin{array}{ll}7 \\
\end{array}$ & q & F & 's & o & F & $\stackrel{\infty}{+}$ & o & in \\
\hline
\end{tabular}




\begin{tabular}{|c|c|c|c|c|c|c|c|c|c|c|c|c|c|c|c|c|c|c|}
\hline ஜ & 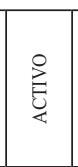 & 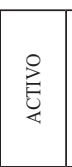 & 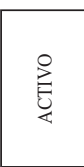 & 主 & 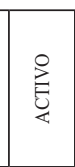 & 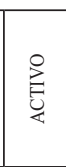 & 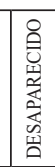 & 龸 & 总 & 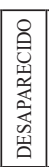 & 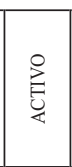 & 良 & 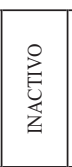 & 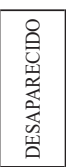 & 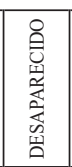 & 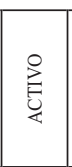 & 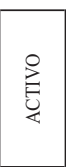 & 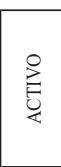 \\
\hline & $\begin{array}{c}\infty \\
\stackrel{\infty}{2} \\
\stackrel{1}{=}\end{array}$ & $\stackrel{B}{=}$ & $\stackrel{\Xi}{\sim}$ & के & 家 & $\begin{array}{l}\text { S. } \\
\text { S. }\end{array}$ & $\begin{array}{l}8 \\
\text { ते }\end{array}$ & $\therefore$ & 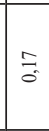 & $\because$ & $\stackrel{0}{\rightarrow}$ & $\stackrel{\circ}{=}$ & $\begin{array}{l}\vec{\infty} \\
\vec{d}\end{array}$ & $\begin{array}{l}\text { : } \\
\text { in }\end{array}$ & ने & 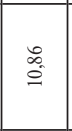 & ב̃ & $\underset{+}{+}$ \\
\hline & 吕 & $\tilde{n}$ & वे & 学 & $\stackrel{\infty}{\stackrel{\infty}{=}}$ & $\frac{m}{6}$ & 莒 & 6 & $\cong$ & $\stackrel{\circ}{\circ}$ & సે & $\bar{్}$ & 吕 & $\overline{8}$ & $\frac{\pi}{\infty}$ & 导 & ळু & f \\
\hline 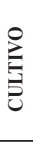 & 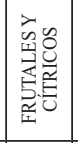 & 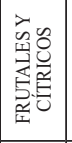 & 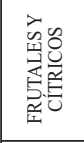 & 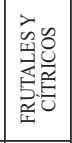 & 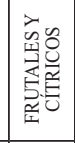 & 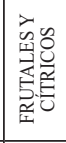 & 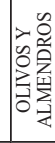 & 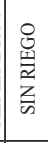 & 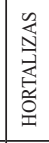 & 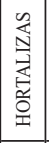 & 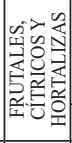 & 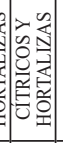 & 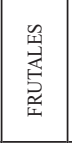 & 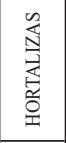 & 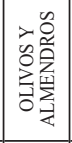 & 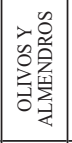 & 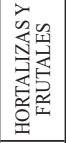 & 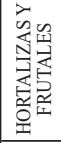 \\
\hline$\widehat{\underline{\underline{z}}}$ & 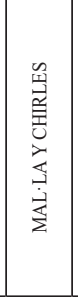 & 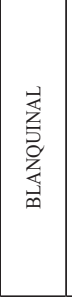 & 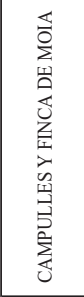 & 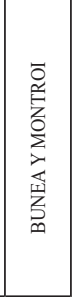 & 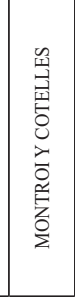 & 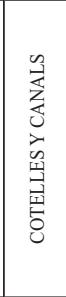 & 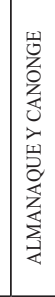 & 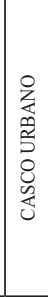 & 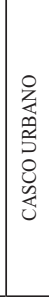 & 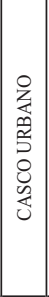 & 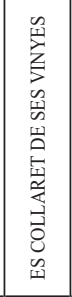 & 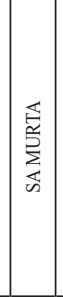 & 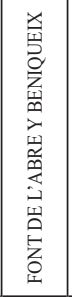 & 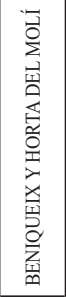 & 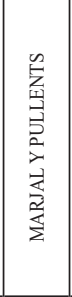 & 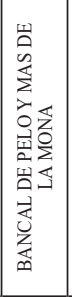 & 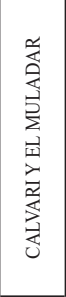 & 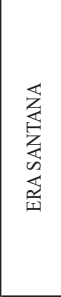 \\
\hline$\sum_{0}^{J}$ & 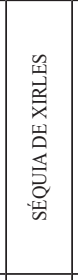 & 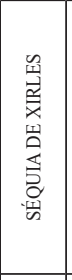 & 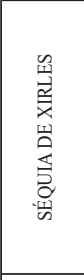 & 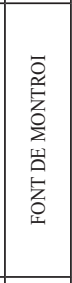 & 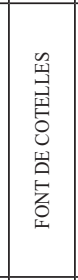 & 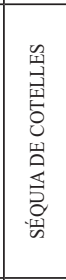 & 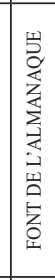 & 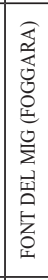 & 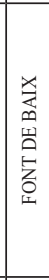 & 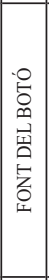 & 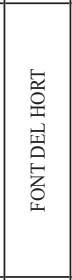 & 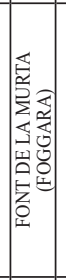 & 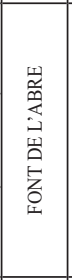 & 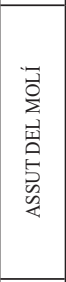 & 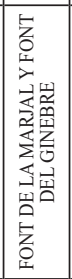 & 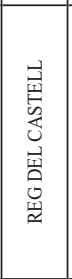 & 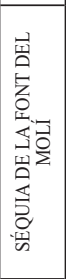 & 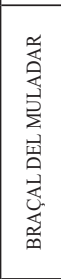 \\
\hline 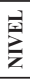 & N & $N$ & N & - & - & $N$ & - & - & - & - & - & - & - & - & - & $m$ & $\sim$ & m \\
\hline 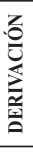 & 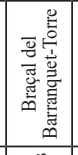 & 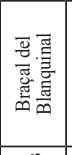 & 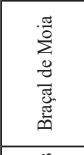 & & & 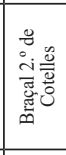 & & & & & & & & & & 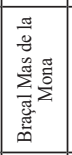 & 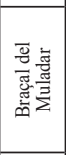 & 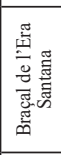 \\
\hline 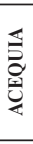 & 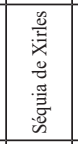 & 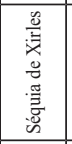 & 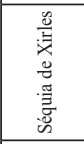 & 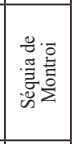 & 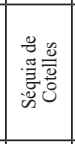 & 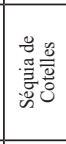 & 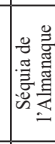 & 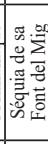 & 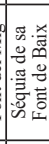 & 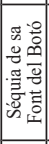 & 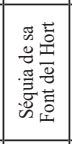 & 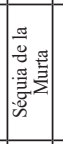 & 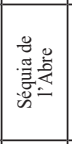 & 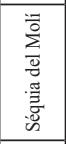 & 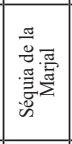 & 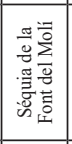 & 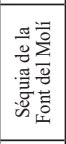 & 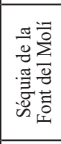 \\
\hline$\sum_{i=1}^{n}$ & 焉氞 & 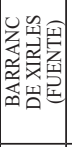 & 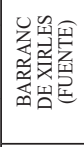 & 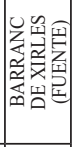 & 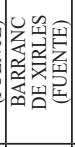 & $\frac{1}{x}$ & $\begin{array}{l}0 \\
\vdots \\
0\end{array}$ & 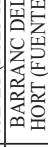 & 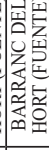 & 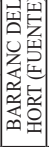 & 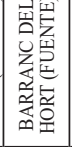 & 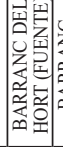 & 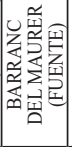 & 要 & 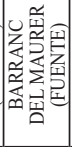 & & 通 & 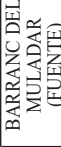 \\
\hline 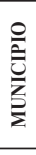 & 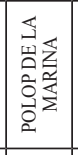 & 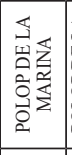 & 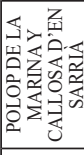 & 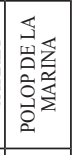 & 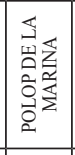 & 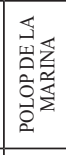 & 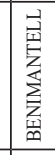 & 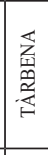 & 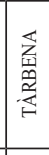 & 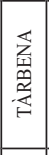 & 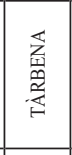 & 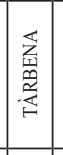 & 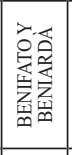 & 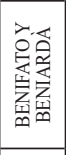 & $\begin{array}{l}\text { 芯 } \\
\text { 产 } \\
\text { 畜 }\end{array}$ & 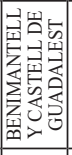 & 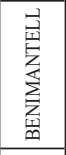 & $\begin{array}{l}\text { 画 } \\
\text { 畜 } \\
\text { 畜 } \\
\end{array}$ \\
\hline ij & $\bar{n}$ & तก & $n$ & is & in & $i$ & in & in & in & 8 & 6 & త & 8 & t & 3 & 8 & 5 & \\
\hline
\end{tabular}




\begin{tabular}{|c|c|c|c|c|c|c|c|c|c|c|c|c|c|c|c|c|c|c|}
\hline ஜ & 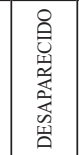 & 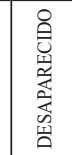 & 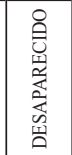 & 总 & 畩 & 主 & 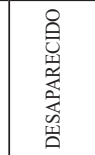 & 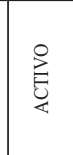 & 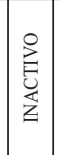 & 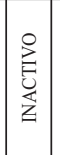 & 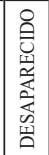 & 效 & 总 & 总 & 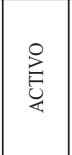 & 㟒 & 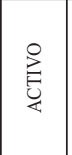 & 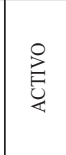 \\
\hline[ & 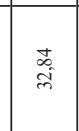 & $\stackrel{2}{2}$ & $\stackrel{\infty}{\sigma}$ & 商 & $\mid \begin{array}{l}\infty \\
\infty \\
\infty \\
0\end{array}$ & $\stackrel{\substack{f \\
=}}{=}$ & $\begin{array}{l}\text { to } \\
\text { so }\end{array}$ & $\begin{array}{l}\bar{\sigma} \\
\stackrel{s}{S}\end{array}$ & 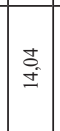 & $\stackrel{\infty}{\sigma}_{\alpha}$ & $\begin{array}{l}0 \\
0 \\
0 \\
0\end{array}$ & तु & $\begin{array}{l}\text { to } \\
\stackrel{\sim}{A}\end{array}$ & $m_{2}^{2}$ & $\begin{array}{l}38 \\
8 \\
0\end{array}$ & $\begin{array}{l}\text { ले } \\
\approx\end{array}$ & : & $\begin{array}{l}n \\
\hat{n} \\
\hat{g}\end{array}$ \\
\hline 5 & สั & శે & $\infty$ & $\underset{\text { I }}{R}$ & $\hat{m}$ & $\stackrel{\infty}{\sigma}$ & : & 가요 & 苋 & $\overrightarrow{i n}$ & กั & $\frac{m}{n}$ & : & g & ڤ̊ำ & 茨 & $\underset{\sim}{ \pm}$ & $\bar{\Xi}$ \\
\hline : & 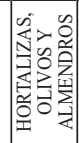 & 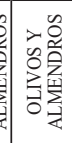 & 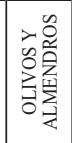 & 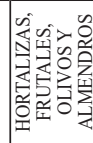 & 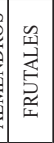 & 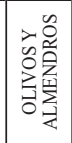 & 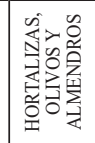 & 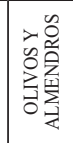 & 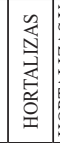 & 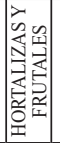 & 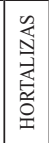 & $\begin{array}{l}0 \\
\stackrel{0}{0} \\
0\end{array}$ & 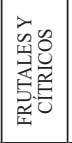 & 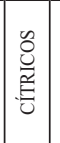 & 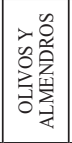 & 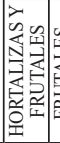 & 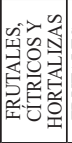 & 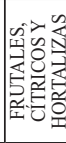 \\
\hline & 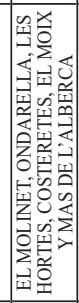 & 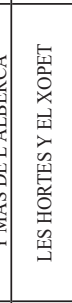 & $\begin{array}{l}\overleftrightarrow{\cong} \\
\text { 兽 }\end{array}$ & 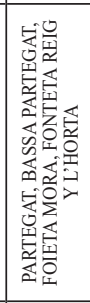 & 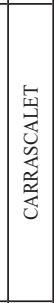 & 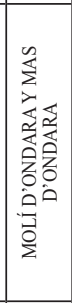 & 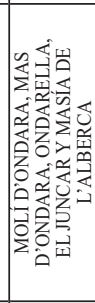 & 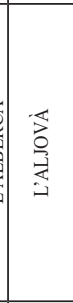 & 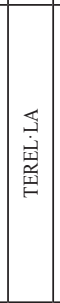 & 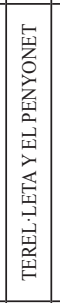 & 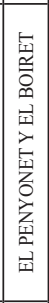 & 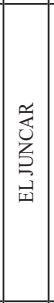 & 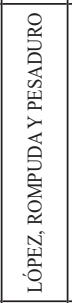 & 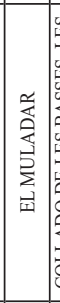 & 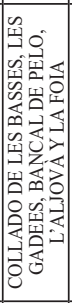 & 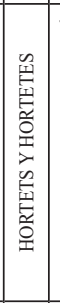 & 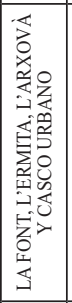 & 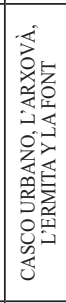 \\
\hline อ & 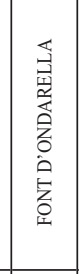 & 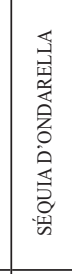 & 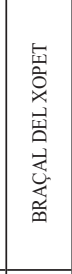 & 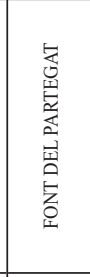 & 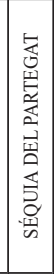 & 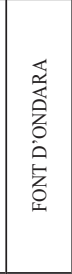 & 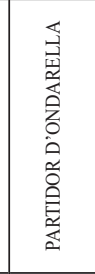 & 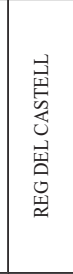 & 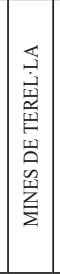 & 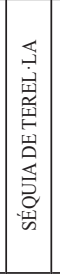 & 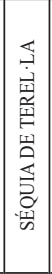 & 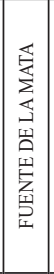 & 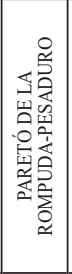 & 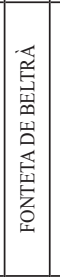 & 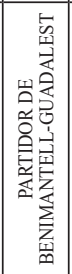 & 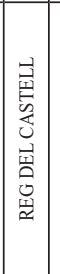 & 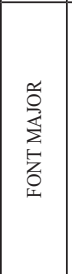 & 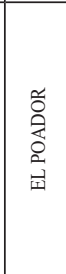 \\
\hline$\sum_{z}$ & - & N & $m$ & - & a & - & a & $m$ & - & $\sim$ & 4 & - & - & - & $\sim$ & m & - & a \\
\hline 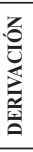 & & 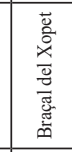 & 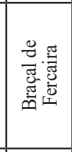 & & 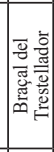 & & 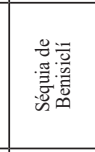 & 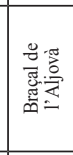 & & 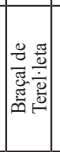 & 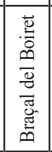 & & & & 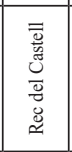 & 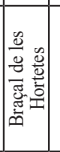 & & 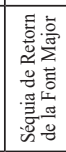 \\
\hline 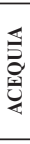 & 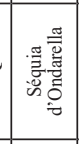 & 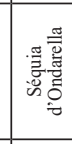 & 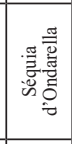 & 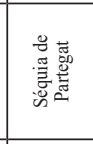 & 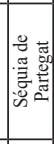 & 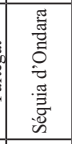 & 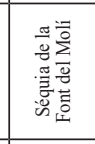 & 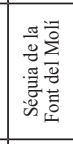 & . & 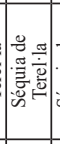 & & 沙 & 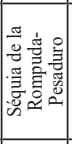 & 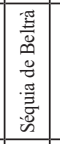 & 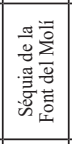 & 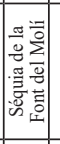 & 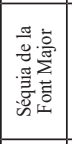 & 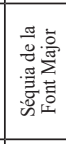 \\
\hline 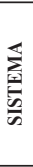 & 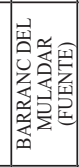 & 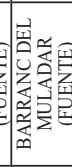 & 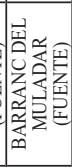 & 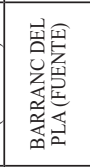 & 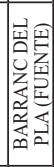 & 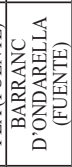 & 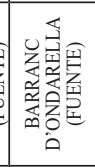 & 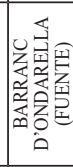 & 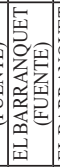 & 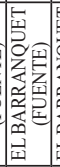 & 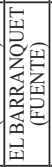 & 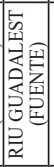 & 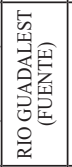 & 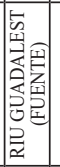 & 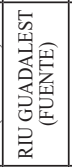 & 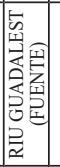 & 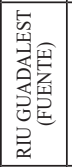 & 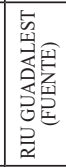 \\
\hline 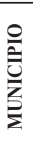 & 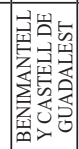 & 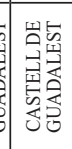 & 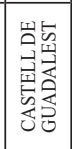 & 童 & 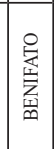 & 息 & 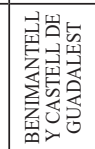 & 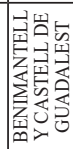 & 离 & 畜 & 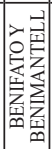 & 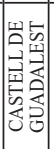 & 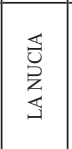 & 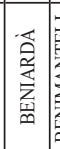 & 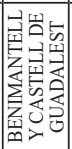 & 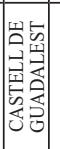 & 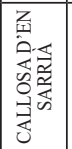 & 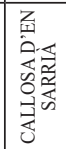 \\
\hline 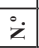 & 8 & 18 & $F$ & $\pi$ & $m$ & $g$ & $\therefore$ & 2 & $=$ & \begin{tabular}{|l|} 
\\
$\stackrel{2}{*}$
\end{tabular} & 2 & $\infty$ & $\bar{\infty}$ & \begin{tabular}{|l|}
$\infty$ \\
\end{tabular} & 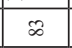 & \begin{tabular}{|l|} 
\pm \\
$\infty$
\end{tabular} & \begin{tabular}{|l|}
$\infty$ \\
\end{tabular} & 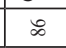 \\
\hline
\end{tabular}




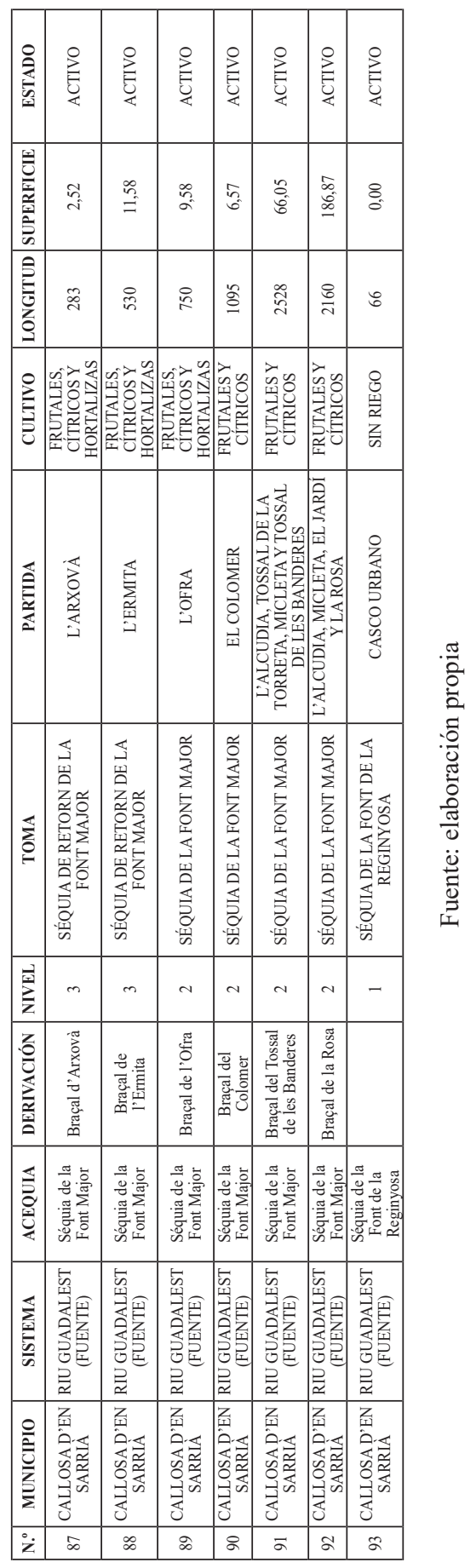




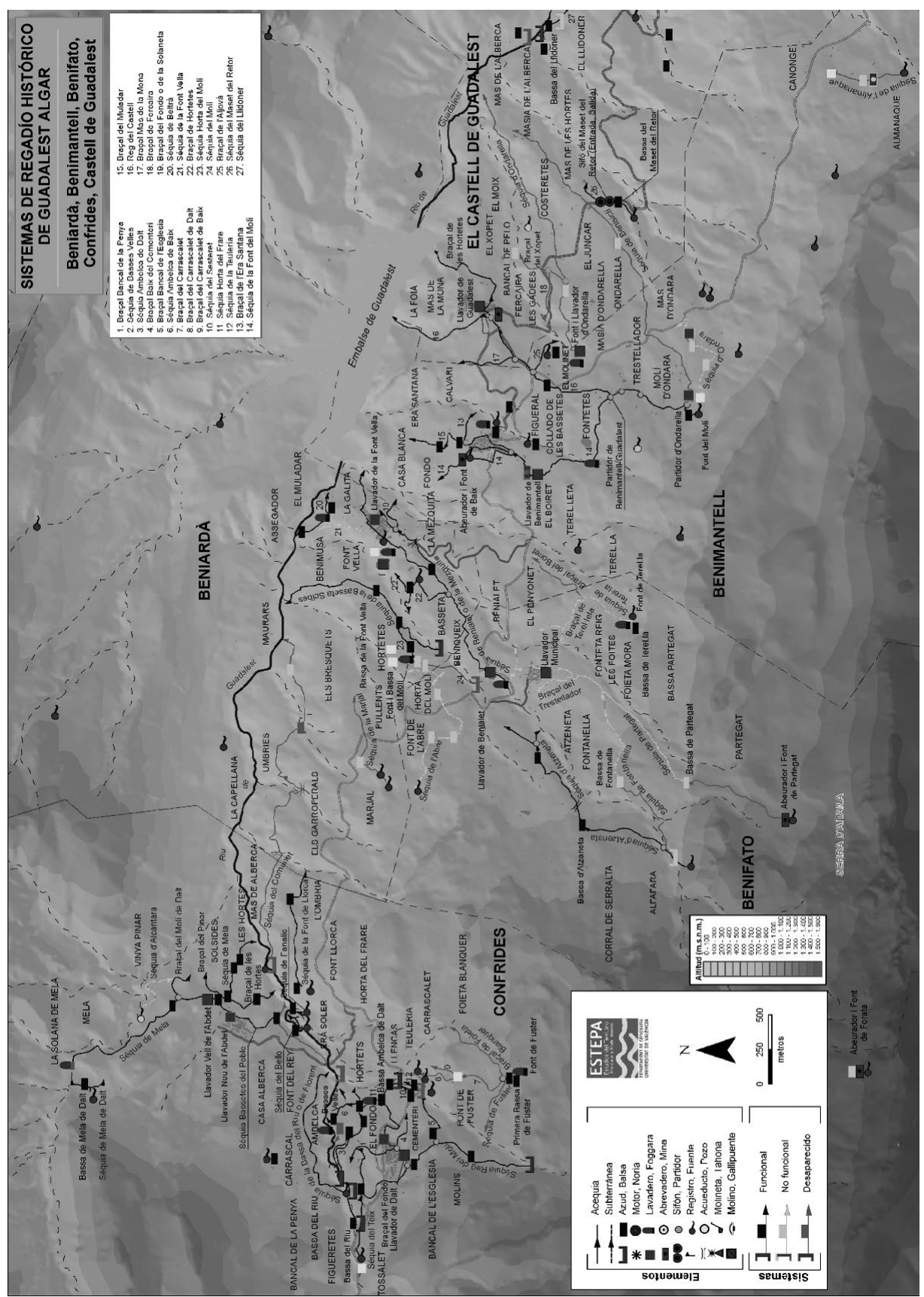




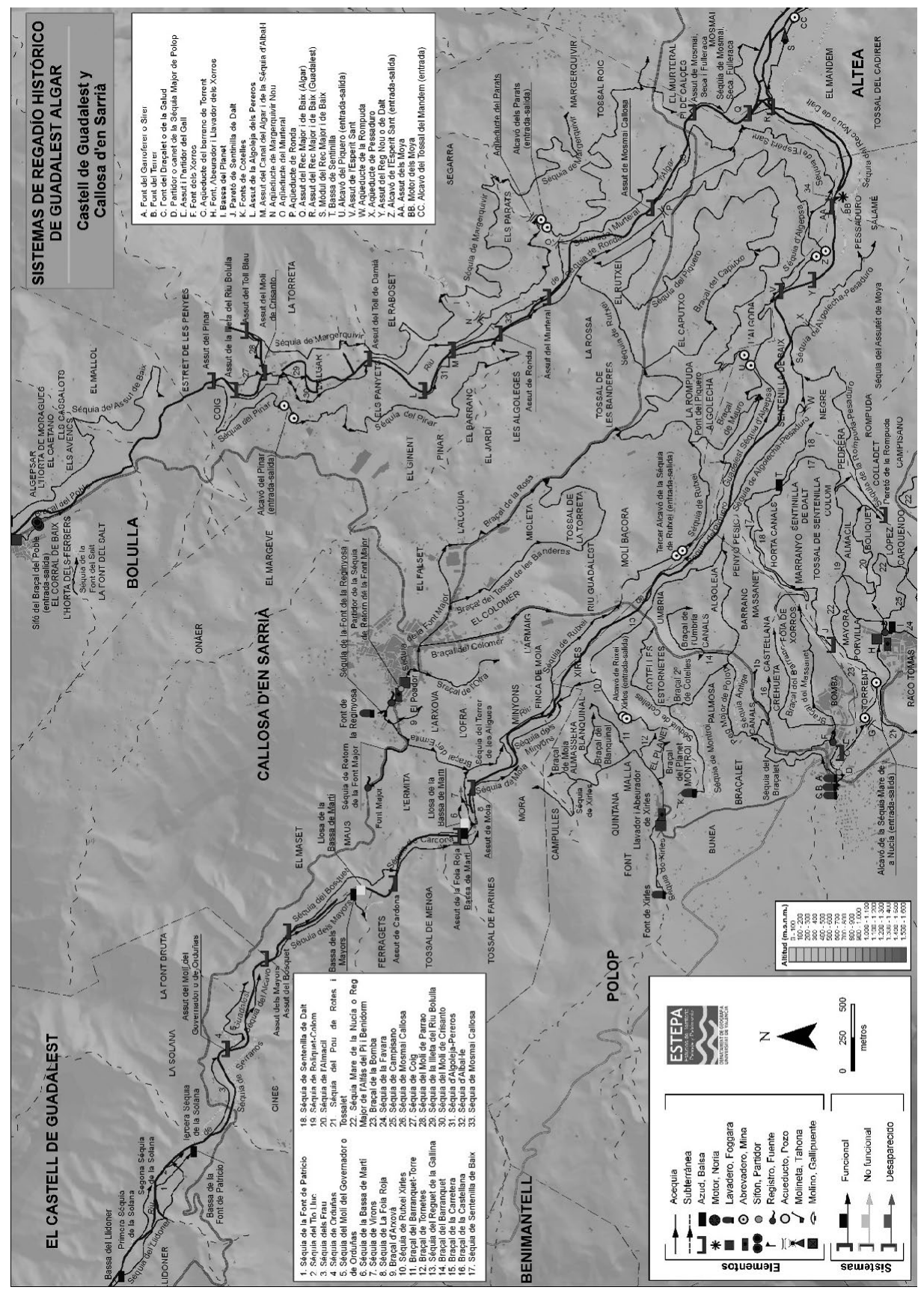




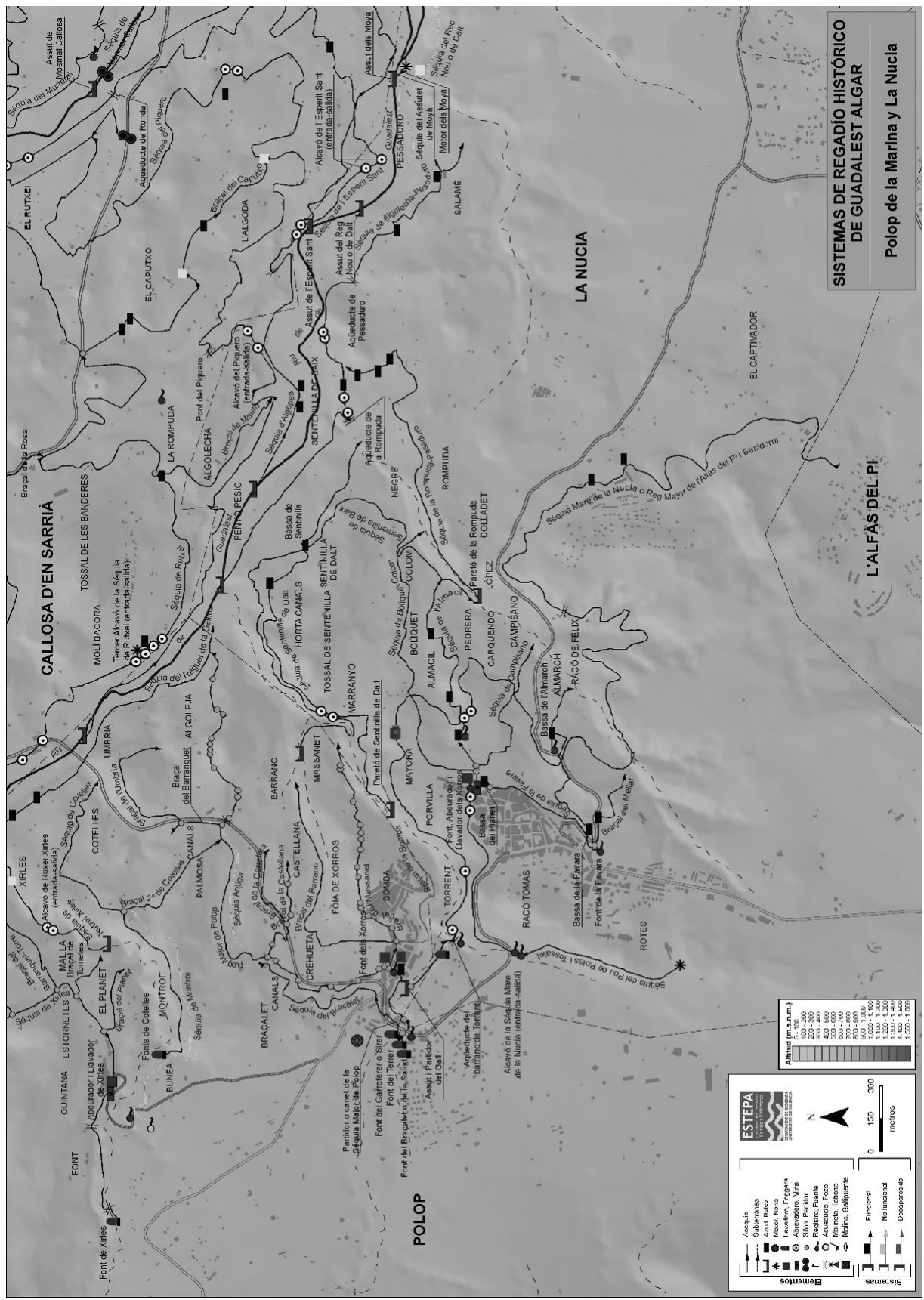




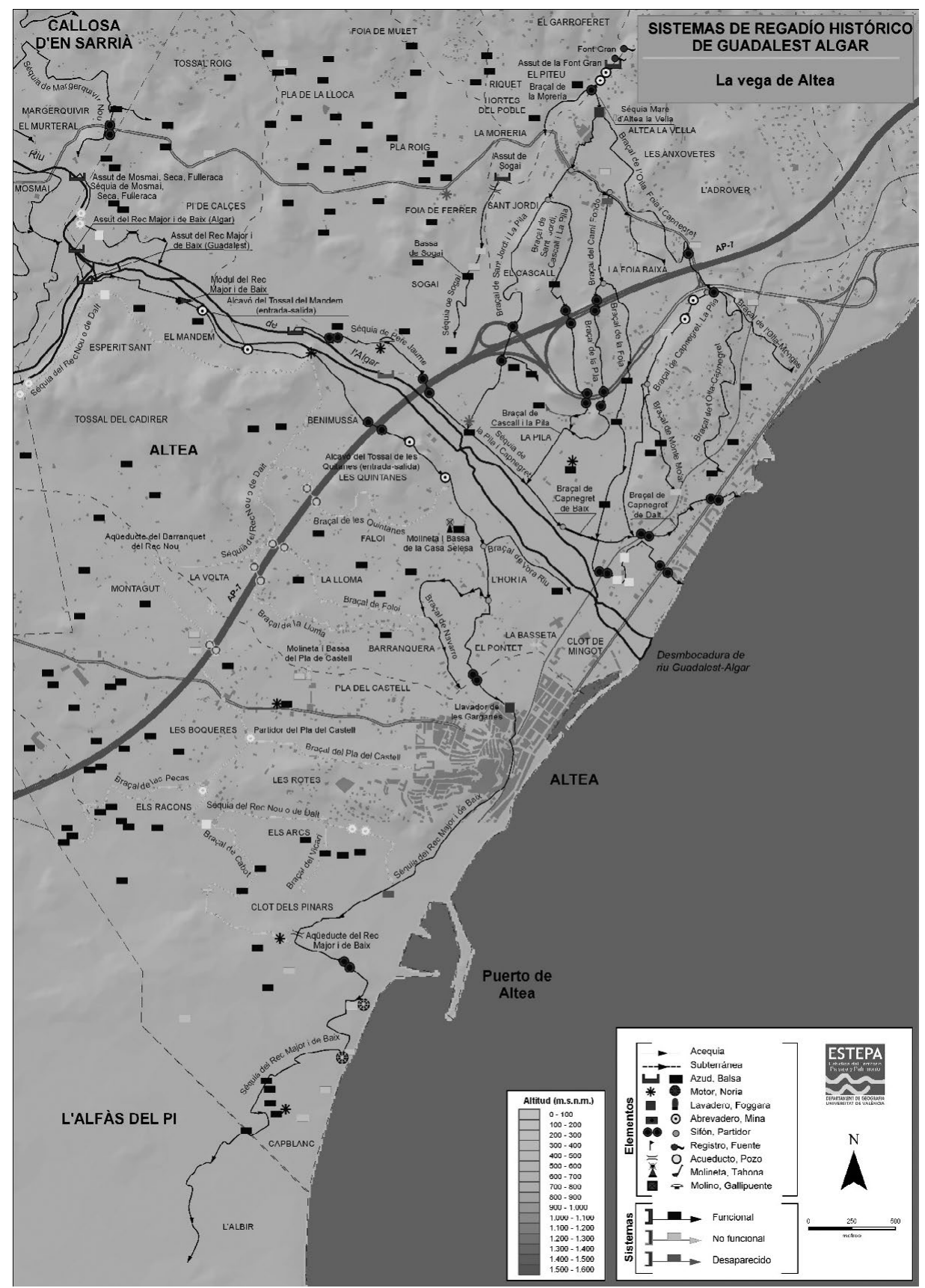




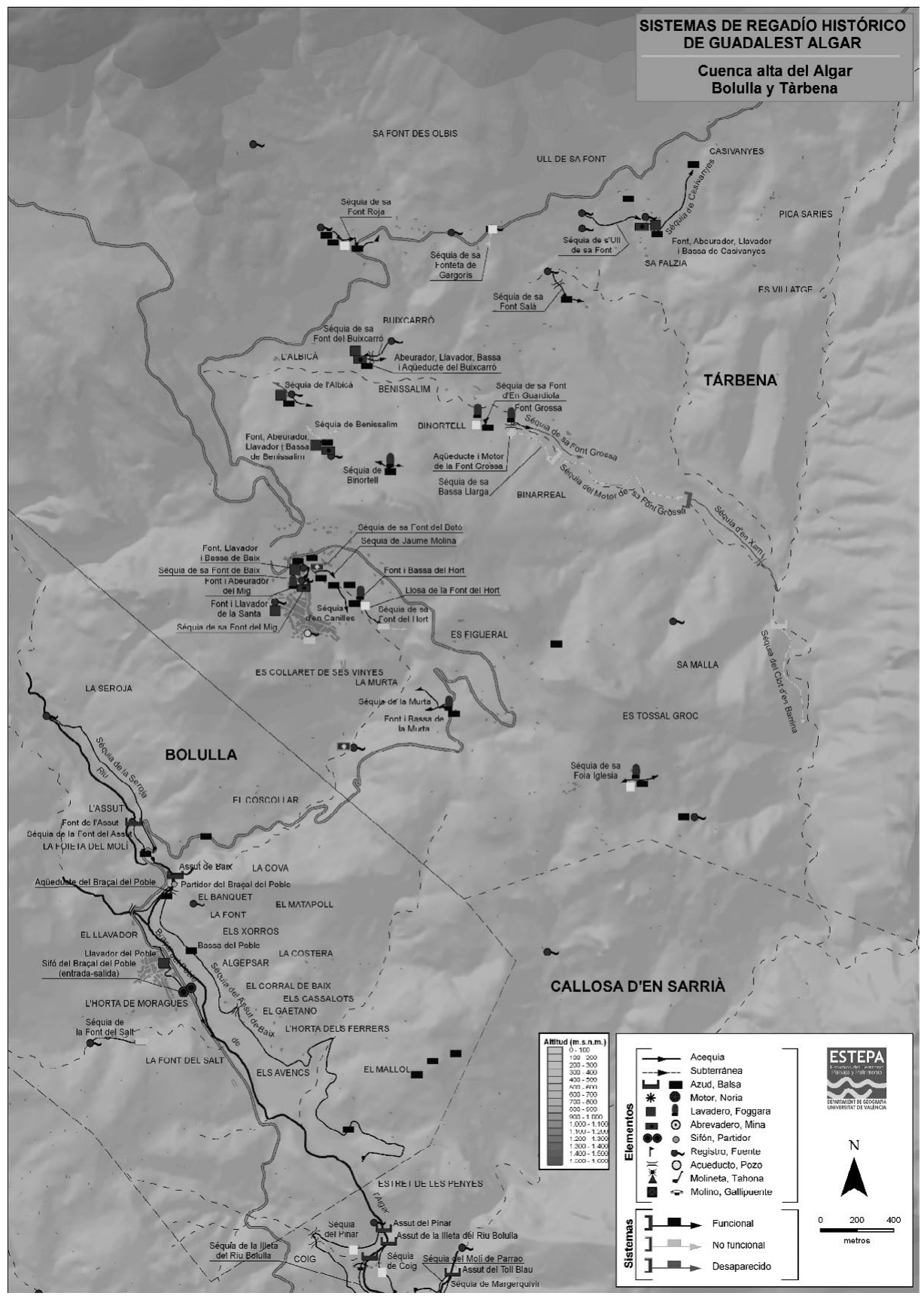


REFLEXIONES FINALES: DUALIDADES TERRITORIALES Y GESTIÓN DEL AGUA

La cuenca del Algar-Guadalest constituye un territorio de gran interés para los estudios de la hidráulica. En una extensión de apenas $200 \mathrm{~km} 2$ se aprecian una serie de constrastes que permiten la identificación de espacios de regadío diferenciados, por las dimensiones, las diferentes captaciones, las morfologías adoptadas de los sistemas de regadío o los elementos tecnológicos utilizados para la captación, transporte y uso del agua. En términos generales se diferencian dos espacios, el interior accidentado dominado por riegos de vega mediante azudes o microrregadíos relacionados con fuentes, galerías drenantes y manantiales; y el sector litoral, piedemontes y llano litoral, por el que discurren acequias en forma de abanico cuyas aguas proceden de azudes y algunos pozos históricos. Esta contraposición entre interior y litoral se repite en términos demográficos y de poblamiento, y económicos: la mayoría de los cerca de 72.000 habitantes de la cuenca del Guadalest-Algar se concentran en la franja litoral (Altea, Alfàs del Pi y La Nucia concentran más del $80 \%$ del total); el cultivo de regadío se concentran en la cuenca media y baja del Algar (nísperos en Callosa d'en Sarrià y cítricos en Altea), y en el resto de la cuenca predomina el secano, con cultivos como la vid, el olivo y el almendro.

La gestión del agua de riego se ha visto modificada a lo largo de los últimos años, debido a la demanda de recursos hídricos para otros fines no agrícolas, especialmente los urbanos. Contextualmente la zona de estudio está emplazada en los dominios adscritos a la Confederación Hidrográfica del Júcar, que actúa como Organismo de Cuenca. Asimismo, se integra en el Sistema de Explotación Marina Baja, que comprende las Unidades de Demanda Agraria de «Riegos del Sindicato Algar-Guadalest» y «Riegos del Canal Bajo del Algar». Este sistema comprende la totalidad de las cuencas del riu Guadalest-Algar y las subcuencas litorales comprendidas entre el límite meridional del término municipal de Benissa y la margen izquierda del riu Algar. Se da la circunstancia que históricamente las aguas del riu Algar se han utilizado para el riego de frutales del término municipal de Callosa d'en Sarrià. Al entrar en vigor la gestión integral realizada por el Consorcio de la Marina Baja, además del regadío, el principal uso del agua del Algar es para el abastecimiento de los importantes núcleos de población de la comarca, incluidos Benidorm y La Vila Joiosa. Esta transferencia de agua se realiza mediante un azud con una estación de bombeo del Consorcio de la Marina Baja, que permite elevar las aguas al embalse de Guadalest. Aguas abajo, a un kilómetrode esta estación de bombeo, también arranca el Canal Bajo del Algar, que tiene su final en el embalse de Amadorio, y permite el riego de zonas situadas entre Altea y Benidorm. Los agricultores ceden parte de sus derechos de uso del agua de excelente calidad para que se destine a abastecimiento urbano, y a cambio reciben aguas residuales depuradas. Una acción 
que permite por una parte abastecer la demanda estival con la regulación de la batería de sondeos del Algar, y por otra parte, facilitar los recursos necesarios para el regadío. En este sentido es destacable no sólo el número de elementos hidráulicos que integran esos sistemas de irrigación, más de 800, sino también los elevados niveles de uso de los mismos, alrededor del 85\%. Una garantía de conservación de unos sistemas tradicionales, vivos, que forman parte del patrimonio hidráulico mediterráneo.

\section{BIBLIOGRAFÍA}

Alberola, A. (Ed.) (1995): Cuatro Siglos de técnica hidráulica en tierras alicantinas. Alicante, Diputación Provincial, Instituto de Cultura Juan Gil Albert.

Alfaro, P. Et Al (2004): Geología de Alicante. XIII Simposio sobre Enseñanza de la Geología Alicante (267 p).

Al-Mudayna (1991): Historia de los regadios en España (... a.C. -1931). Ministerio de Agricultura, Pesca y Alimentación, Madrid. 743 pp.

Amillo Alegre, F (2007): «Musulmanes y Cristianos en la Marina Baixa durante los siglos XIII, XIV, XV y XVI» en Revista Polop de la Marina. Festes del Porrat (del 14 al 17 d'agost 2007). pp 91-94

Amillo Alegre, F (2010): «El Régimen señorial en Polop» en Revista Polop de la Marina. Festes del Porrat (del 14 al 17 d'agost 2010). pp 84-93

BoleA, J.A. (1969): Régimen jurídico de las Comunidades de Regantes. Escuela Nacional de Administración Pública, Madrid.

Boluda, A, Galiana, J y Pons, V (1991): El Vínculo de los Bou, La documentación de Callosa d'En Sarrià y Tàrbena en el archivo de los Condes de Orgaz. Instituto de Estudios Juan Gil Albert, Alicante. 165 pp.

Caja de Ahorros de Valencia (1982): La Marina Baixa. Valencia (67 p).

CAVANILles, A.J. (1795-1797): Observaciones sobre la historia natural, geografia, agricultura, población y frutos del Reyno de Valencia. Reproducción Facsímil. Ediciones Albatros, València, 1985. 2 vols.

Ferrer Navarro, R (2000): Conquista y Repoblación del Reino de Valencia». Del Senia al Segura. Valencia.

Galiana, A. (2001) Història natural de la Marina Baixa. Club Universitario, Alicante (175 p).

Gil, A. y Morales, A. (1992): Hitos históricos de los regadíos españoles. Ministerio de Agricultura, Pesca y Alimentación, Madrid. 415 pp.

GLICK, T. F. (1988): Regadio y sociedad en la Valencia medieval. Traducción de Adela Amor; edición a cargo de Ramón Ferrer Navarro. Del Cenia al Segura, València. 413 pp.

González, I. (1992): Fábricas hidráulicas españolas. Ministerio de Obras Públicas y Transportes, CEHOPU. Ed. Turner Libros. 534 pp.

Hermosilla, J. (Dir.) (2010): Los Regadios Históricos Españoles: paisajes culturales, paisajes sostenibles. Colección Gestión tradicional del agua, patrimonio cultural y 
sostenibilidad, n. ${ }^{\circ}$ 3. Madrid, Ed. Ministerio de Medio Ambiente y Medio Rural y Marino. 600 pp.

Hermosilla, J. e Iranzo, E. (2014): Claves geográficas para la interpretación del patrimonio hidráulico mediterráneo. A propósito de los regadíos históricos valencianos. Boletín de la Asociación de los Geógrafos Españoles. N. ${ }^{\circ}$ 66. Págs. 49-66.

KirChner, H. (1999): «Observaciones a propósito de la hidráulica andalusí». En Morilla Critz, J., Gómez Pantoja, J., y Cressier, P.: Impactos exteriores sobre el mundo rural mediterráneo. Del imperio romano a nuestros días. Ministerio de Agricultura, Pesca y Alimentación, Madrid. Pp. 139-161.

Llorens BARBer, R (1988): Historia de Altea. Siglo XVIII. Altea 424 pp.

López, A. y Rosselló, V.M. (1978): Geografía de la provincia de Alicante. Excma Diputación Provincial de Alicante (615 p)

López Gómez, A. (1964): «Riegos y cultivos en las huertas valencianas». Aportación española al XX Congreso Geográfico Internacional, Inst. Elcano-Inst. Estudios Pirenaicos. C.S.I.C. Pp. 89-100 y 8 láminas.

López Gómez, A. (1975): «El origen de los riegos valencianos II. La división del agua». Cuadernos de Geografia, N. ${ }^{\circ} 17$. Pp. 1-38.

MalpiCAS, A. (Comisario) (1995): El agua en la agricultura de Al-Andalus. Lunwerg Editores, Barcelona. 189 pp.

MALUQUER, J. (1985): «La despatrimonialización del agua: movilización de un recurso natural fundamental». En GARcía SANZ y GARRABou: Historia Agraria de la España Contemporánea. Ed. Crítica. Pp. 275-296.

Marco, J.B.; MateU, J.; Romero, J. (1994): Regadios Históricos Valencianos: propuestas de rehabilitación. Conselleria d'Agricultura I Pesca, Servei d'Estudis Agraris I Comunitaris, Generalitat Valenciana. $158 \mathrm{pp}$.

MARCO, J.B. (1999): «La rehabilitació del regadiu històric valencià: reptes I estrategies». En Hortes valencianes: la fi d'un mite?. Mètode, N. ${ }^{\circ} 22$. Universitat de València. Pp. 32-34.

Martínez SanMartín, L.P. (1993): «El estudio social de los espacios hidráulicos. De la Maîtrise de l'eau a la questió hidràulica». Taller d'Història, ‥ ${ }^{\circ} 1$.

MATEU, J. (1999): «Una aproximación a les hortes valencianes». En Hortes valencianes: la fi d'un mite?. Mètode, N. ${ }^{\circ} 22$. Universitat de València. Pp. 14-15.

Morales, A. (1998): «The mediterranean van agriculture». Boletín de la Asociación de Geógrafos Españoles. Pág 163-188.

Pastor I FluixÀ, J (2005): Les Baroníesde Calp, Benissa, Teulada I Altea. Ajuntament de Calp, Alacant. 541 pp.

Piqueras, J. (1993): «Les obres de reg valencianes: l'origen I l'estat actual». Lauro, N. ${ }^{\circ}$. Pp. 31-40.

Pla Alberola, P (1983): La Población del Marquesado de Guadalest en el siglo XVII. Instituto de estudios alicantinos, Alicante. $218 \mathrm{pp}$.

Salvá Ballester, A (1960): La Villa de Callosa de Ensarriá. Monografía Histórica Documentada. Instituto de Estudios Alicantinos. Diputación Provincial. 2 vol. 294 pp. 
SAnchis, C.; Hermosilla, J.; Iranzo, E. (2004): «Entorn al patrimoni hidràulic del regadiu històric valencià». Pp. 223-236. En Patrimoni rural valenciano, SAITABI, N. ${ }^{\circ} 54$. Pp. 270.

SAn José, F (2010): «Las Fuentes de la Mata y el Tosalet» en Revista Polop de la Marina. Festes del Porrat (del 14 al 17 d'agost 2010). pp.101-103

Torregrosa Martí, M. ${ }^{\mathrm{a}}$ T (2009): La gestión del agua en la Marina Baja (Alicante). Corts Valencianes, D.L. (265p).

IGME y DPA (2010): Acuíferos de Sierra Aitana y su entorno (Alicante). Minesterio Ciencia e Innovación y Diputación de Alicante (111 p).

El presente artículo se ha servido de la experiencia acumulada durante las investigaciones de la unidad ESTEPA (Departament de Geografia, Universitat de València), mediante la elaboración de proyectos sobre riegos tradicionales y el patrimonio hidráulico desarrollados por el territorio valenciano a lo largo de los últimos quince años. Bajo la dirección del profesor Jorge Hermosilla, parte de estas investigaciones han sido publicadas en la Coleccioón Regadios Históricos Valencianos, de la Dirección General de Patrimonio Cultural Valenciano, la Universitat de Valeència y la Confederacioón Hidrográfica del Júcar: El Patrimonio del agua en el Valle de Ayora-Cofrentes (1999); Los sistemas de regadio en La Costera. Paisaje y Patrimonio (2003); La Arquitectura del agua en el Riu Magre. Alcalans-Marquesat (2004); El regadio histórico en la comarca de Requena-Utiel. Geografia y Patrimonio (2005); Los Riegos de la Safor y la Valldigna. Agua, Territorio y Tradición (2005); Los Paisajes de Regadio en el Alto Palancia. Sistemas y elementos hidráulicos (2006); Las Riberas del Xúquer: Paisajes y patrimonio Valenciano (2006); Los regadios tradicionales del Vinalopó. Alto y Medio (2007); El patrimonio hidráulico del Bajo Túria: L'Horta de València (2007); Las vegas tradicionales del Alto Turia: sistemas y paisajes de regadio (2008); Los regadios históricos del Turia Medio: La Serranía y el Camp de Turia (2009); Los regadios históricos del Baix Millars-La Plana (2009); Los regadios tradicionales y el patrimonio hidráulico del Alto Mijares (2010); Los riegos tradicionales de La Marina Alta: las cuencas hidrográficas del Gorgos y Girona (2012); y El patrimonio del regadio tradicional de la Marina Baixa: la cuenca del Amadorio (2015), coeditados por el Servicio de Publicaciones de la Universitat de València y la Dirección General de Patrimonio Cultural Valenciano. 